\title{
Contractility of the epididymal duct: function, regulation and potential drug effects
}

\author{
V Elfgen ${ }^{1, *}$, A Mietens $^{1, *}, \mathrm{M} \mathrm{Mewe}^{2}, \mathrm{~T} \mathrm{Hau}^{1}$ and R Middendorff ${ }^{1}$ \\ ${ }^{1}$ Signaling Group, Institute of Anatomy and Cell Biology, Justus Liebig University Giessen, Giessen, Germany and \\ ${ }^{2}$ Department of Cellular and Integrative Physiology, University Medical Center Hamburg-Eppendorf, \\ Hamburg, Germany
}

Correspondence should be addressed to R Middendorff; Email: Ralf.Middendorff@anatomie.med.uni-giessen.de

*(V Elfgen and A Mietens contributed equally to this work)

\begin{abstract}
During their transit through the epididymis, spermatozoa mature and acquire motility and fertilizing capacity. The smooth muscle cells (SMCs) of the epididymal duct are thought to be responsible for the adequate transport of spermatozoa. Thus, precise regulation of SMC function also represents a prerequisite for sperm maturation thereby contributing to male fertility. In this review, we would like to highlight various aspects of epididymal SMC function and discuss several angles with respect to regulation of contraction and relaxation. Different to the vas deferens, where disturbed SMC pathways resulting in male infertility could be defined, comparable information is missing in the epididymis. We therefore include some vas deferens data which could also be useful for a better understanding of epididymal SMC function. Furthermore, we would like to draw attention to drugs used in clinical practice and their potential (side) effects on contractions in the epididymis.

Reproduction (2018) 156 R125-R141
\end{abstract}

\section{Introduction}

In man, the epididymis contains a caput, corpus and cauda region (Fig. 1A) and is further subdivided into segments (Holstein 1969) by connective tissue septa (Turner et al. 2003, Holstein 2008, Domeniconi et al. 2016). In different species, the number of segments varies (Turner et al. 2003, 2007, Hinton et al. 2011). The main structural component of the organ is a single epididymal duct that is upstream (in the caput) connected to the rete testis by 8-12 efferent ducts and downstream (in the cauda) to the vas deferens (Fig. 1A).

Every second, the epididymis receives roughly 1000 1500 spermatozoa that have been released by the testis (Amann \& Howards 1980). They need to transit up to $6 \mathrm{~m}$ in human, $3 \mathrm{~m}$ in rat and $1 \mathrm{~m}$ in mice through the highly convoluted (Hinton et al. 2011; Fig. 1A and B) epididymal duct in a suitable manner to acquire motility and fertilizing ability (Robaire \& Hinton 2015). Total transit time is around 10 days, but differences between species exist (Robaire \& Hinton 2015). Proper sperm maturation and transport by the coordinated action of the epididymal SMCs are thus intricately interwoven and require delicate regulation. Beside a brief overview on their structure, the function, regulation and potential clinical relevance of epididymal SMCs is at the focus of this review.

\section{Mechanisms of transport of spermatozoa within the epididymis}

In general, transport of spermatozoa within the epididymis might be affected (i) by smooth muscle cell (SMC) contractions (see 'Muscle contraction' section), (ii) the luminal fluid (see 'Luminal fluid and sperm transport' section) and (iii) presumably specialized ciliated cells (see 'Transport effects by kinocilia' section).

\section{Luminal fluid and sperm transport}

In the very proximal part of the epididymis, transport of spermatozoa is influenced by a constant fluid production originating from the testis. Nearly all fluids are reabsorbed in the efferent ducts and the initial segment. In fact, in tammar and in rat around $90 \%$ of the fluid (of the testis) entering the efferent ducts is reabsorbed (Turner 1984, Jones \& Clulow 1987, Clulow et al. 1994). Hormonal aspects of fluid resorption are mentioned below (see 'Estrogens' in 'Regulation by hormones' section).

\section{Transport effects by kinocilia}

The efferent ducts consist of an epithelial layer surrounded by SMCs (Kierszenbaum \& Tres 2016). Beside cells involved in resorption and secretion, the epithelial layer also comprises ciliated cells (Kierszenbaum \& Tres 2016). 
A

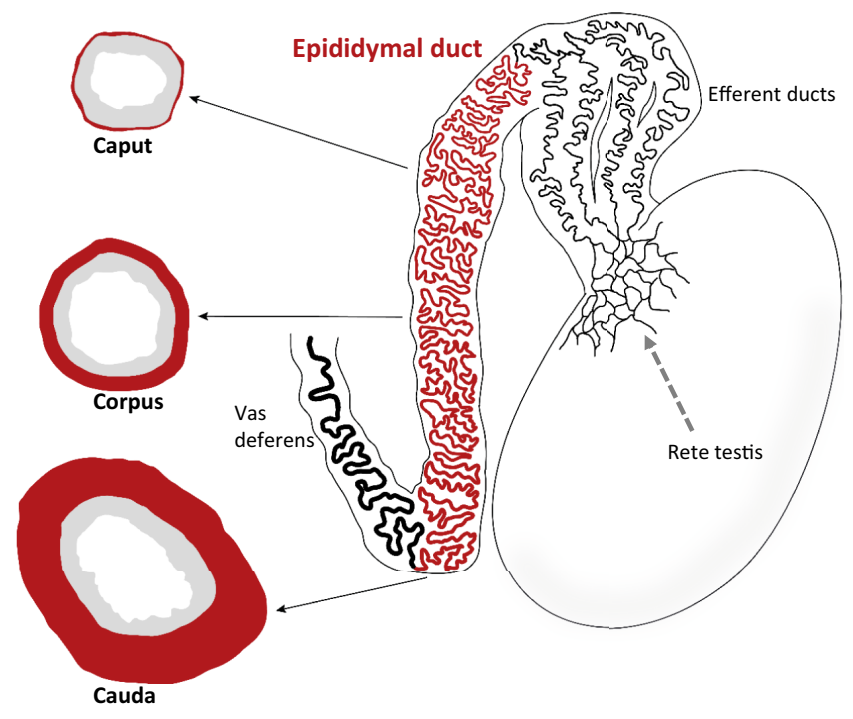

B

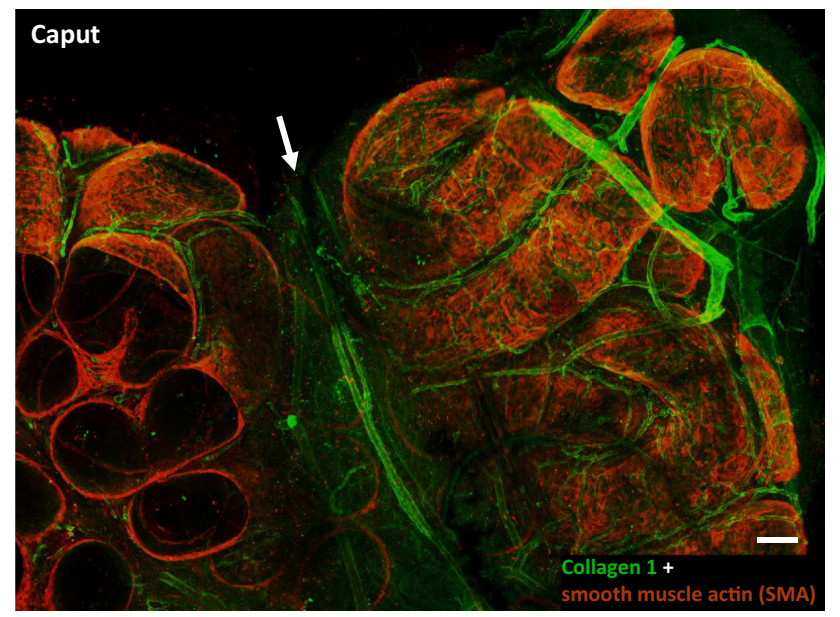

Figure 1 The smooth muscle cell layer of the epididymal duct. (A) The diagram illustrates the human epidiymal duct (red) with its neighboring structures and the increasing thickness of the SMC layer (cross sections, red) along the duct (Baumgarten et al. 1971). (B) The three dimensional aspect of the proximal part of the rat epididymis is visualized after clearing of the tissue by CLARITY. The convoluted epididymal duct is illustrated by staining of the smooth muscle cell layer (using SMA antibodies, red). In addition, the architecture of interstitial blood vessels and the connective tissue septum (arrow) between two segments is visible (collagen 1 staining, green).

In contrast to organs such as the oviduct or the airways where the role of kinocilia for transport function is established (Klein et al. 2009, Noreikat et al. 2012), the role of ciliated cells in the epididymis is less clear and has not yet been addressed experimentally to our knowledge. Ciliated cells of the efferent ducts were recently suggested to contribute to the transport of spermatozoa in the epididymis (Robaire \& Hinton 2015).
Similar to M2 and M3 (and M1) muscarinic acetylcholine receptors $(\mathrm{mAChR})$ shown to be involved in cilia-driven transport in the airways (Klein et al. 2009), cholinergic contribution to the transport of spermatozoa is also thinkable, since M2, M3 (and M1) mAChRs were also described in ciliated cells of the efferent ducts (Siu et al. 2006). In addition, the presence of NOS in ciliated cells suggests that $\mathrm{NO}$ also could have an impact on sperm transport (Davidoff \& Middendorff 2000).

\section{Muscle contraction}

The relevance of SMC contractility for the transport of spermatozoa seems to be common sense. To our knowledge, however, actual sperm transport as a result of SMC contractility has only occasionally been reported. This chapter intends to give an overview on structure and function of the SMC layer.

\section{Structure and contraction of the smooth muscle layer of the epididymal duct}

All efferent ducts become convergent in one single epididymal duct consisting of an epithelial layer and the surrounding SMC layer (Holstein 1969, Kierszenbaum \& Tres 2016). The epithelium is classified as a pseudostratified epithelium with (immotile) stereocilia pointing to the lumen (Kierszenbaum \& Tres 2016). The SMC layer (Fig. 1A and B) consists of thin SMCs that are predominantly arranged in a circular manner. In the human epididymis, bundles of collagen fibers are found among SMCs and true fibroblasts were also described (Holstein 1969, Baumgarten et al. 1971). The thickness of the SMC layer increases along the epididymal duct from caput to cauda (Holstein 1969, Baumgarten et al. 1971 and Fig. 1A). In the corpus, outer bundles of longitudinally and obliquely orientated SMCs join the circularly arranged inner smooth muscle layer (Holstein 1969, Baumgarten et al. 1971). Toward the cauda, additional large SMCs appear in the outer parts of the duct (Holstein 1969) resulting in a complete further SMC layer (Baumgarten et al. 1971) with a predominantly longitudinal orientation of the cells. These large SMCs are more differentiated than the smaller, thin SMCs (Holstein 2008). These thin SMCs are also described as myofibroblasts by some authors (Mewe et al. 2006b) and thought to be spontaneously contracting (Holstein 2008). Interestingly, in the quiescent vas deferens only large SMCs were found (Holstein 1969). This arrangement with large SMCs and lacking spontaneous contractility might be important in the context of ejaculation.

Data on contractions of the epididymal duct, which are difficult to obtain from human material, are available from several species. In most parts, the epididymal duct is characterized by spontaneous rhythmic contractions as shown by in vivo (Muratori \& Contro 1951, Knight 1974, Hib 1976) and in vitro (Hib \& Caldeyro-Barcia 
1974, Markkula-Viitanen et al. 1979, Talo et al. 1979) experiments. From caput to cauda, contractile frequency decreases while amplitude increases (Risley \& Skrepetos 1964, Talo et al. 1979, Mewe et al. 2006b). In the distal part of the cauda, which stores spermatozoa until ejaculation, only sporadic contractions (Risley \& Skrepetos 1964, Talo et al. 1979, Hib 1988) with areas devoid of any spontaneous contractility (Mewe et al. 2006b) were described. Contractions can spread in both directions and occur against a rising gradient in hydrostatic pressure from caput to cauda (Johnson \& Howards 1976, Pholpramool \& Triphrom 1984).

In addition, peristaltic movements of the duct have been observed in all parts of the epididymis ((Risley \& Skrepetos 1964, Hib \& Caldeyro-Barcia 1974, Talo et al. 1979, Studdard et al. 2002, Mietens et al. 2014) our unpublished results). When injecting oil droplets into the caput of the epididymal duct, droplets disperse along the duct. Slow and fast transport in both directions and pendular movements of luminal content were described (Jaakkola \& Talo 1982, 1983).

Interestingly, spontaneous contractions of the duct do not only occur in the adult epididymis, but have already been found before mature spermatozoa occur, i.e. also in the prenatal and postnatal epididymis (van de Velde \& Risley 1963). This is of interest since polysialylated neural cell adhesion molecule (NCAM) was detectable among SMCs of the epididymal duct before puberty (Simon et al. 2015). Polysialylated NCAM is known to prevent the adhesion of cells and thus could theoretically also disturb well-regulated contractions of a SMC layer. Nestin, often preceding expression of polysialylated NCAM during development, does however not mark SMCs of the postnatal epididymal duct (Reckmann et al. 2018), but instead marks the vascular SMCs at this time period (Reckmann et al. 2018) as shown before in testis (Davidoff et al. 2004) and lung (Saboor et al. 2016).

\section{Regulation of contractility}

In the cauda region, responsible for storage and emission of sperm, SMC activation by adrenergic nerve fibers is well described (Baumgarten et al. 1971). Knowledge about the regulation of smooth muscle function (responsible for sperm transport) in the other parts of the epididymis is however sparse, but various mechanisms may be of importance. Below, we present contributing factors like neuronal input, hormonal, epithelial and sperm influences.

\section{Neuronal input}

Early investigations on tissue from stillborn children showed that caput and corpus epididymis are supplied by few nerve fibers whereas the cauda is more densely innervated (Mitchell 1935). These differences of the innervation pattern were also revealed in adult human tissue (Baumgarten et al. 1968) and other species (El-Badawi \& Schenk 1967, Kaleczyc et al. 1993). This finding is in agreement with the special function of the cauda to instantaneously contribute to emission.

Nerve fibers of the epididymis include sympathetic, parasympathetic, peptidergic (e.g. neuropeptide $\mathrm{Y}$ (NPY), vasoactive intestine polypeptide (VIP), substance P, GCRP, L-enkephalin, somatostatin), purinergic or nitrergic neurotransmitter fibers (Kunts \& Morris 1946, Risley \& Skrepetos 1964, Baumgarten et al. 1968, Nouhouayi \& Negulesco 1985, Ventura \& Pennefather 1991, Dun et al. 1996). Some important aspects are discussed below.

\section{Adrenergic input}

The male reproductive tract receives sympathetic input via adrenergic innervation. In human and rat epididymis, alpha1-adrenergic receptors, known to bind noradrenaline and adrenaline (Graham et al. 1996) were described with a predominance of alpha1Aadrenoreceptors (Queiroz et al. 2002) and localized to blood vessels, epithelial cells and SMCs (Queiroz et al. 2008). Increasing noradrenaline concentrations from testis and proximal epididymis toward the vas deferens (Baumgarten et al. 1971) and a higher density of alpha1A-adrenoreceptors were found in the SMCs closer to the cauda epididymidis (Queiroz et al. 2002), which
A

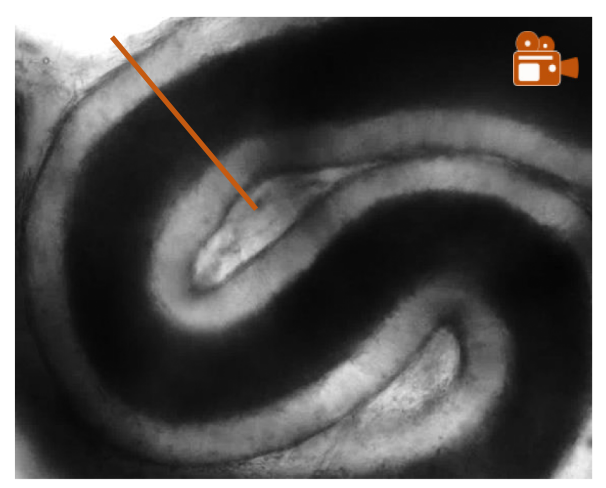

B

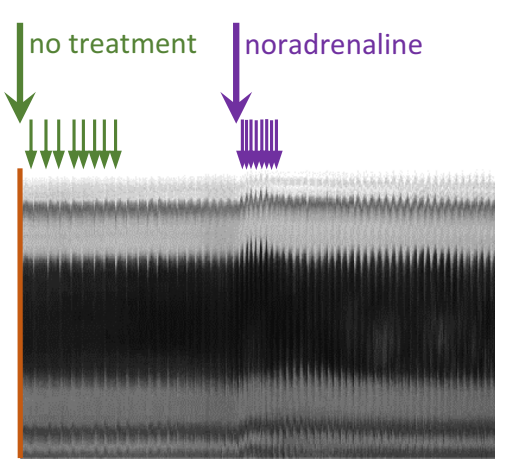

Figure 2 Visualization of noradrenaline effects on spontaneous contractility. (A) Snapshot of a rat epididymal duct section (caput) from a time-lapse imaging movie (Video 1). The time stack was virtually dissected through a plane indicated by the orange bar. (B) Each contraction elicits a small movement of the epididymal duct with changes of its diameter resulting in a series of spikes (marked by vertical arrows). The green arrows show the contractile activity without treatment, while the purple arrows represent the noradrenaline effect. (Figure and Video: courtesy by Christina Seidel.) 
emphasizes the relevance of alpha1-mediated signaling during emission (Kaplan 2009). In addition to its proposed main function in the cauda epididymidis during emission of sperm, noradrenaline was shown to enhance SMC contractions (Fig. 2 and Video 1) also in other regions of the epididymis (Mewe et al. 2006a, 2007, Mietens et al. 2014). Organ bath studies over the length of the bovine duct (Fig. 3), however, showed the maximum contractile response to noradrenaline in the mid-part of the cauda (Mewe et al. 2007). Functional studies using alpha2 agonists and blockers showed an influence also of alpha2-adrenergic receptors on contraction, especially in proximal parts of the duct (Chaturapanich et al. 2002, Mewe et al. 2007). Here alpha2-mediated effects were suggested to be more important than alpha1-mediated ones (Mewe et al. 2007). So far, the exact contributions of the different alpha-adrenoreceptor subtypes to contractile epididymal function have only begun to be explored and require further investigation to identify potential alterations in pathologic conditions.

\section{Video 1}

Noradrenaline enhances SMC contractions. The video (http://movie-usa.glencoesoftware.com/video/ 10.1530/REP-17-0754/video-1) from the online version of the article is available at https://doi.org/10.1530/ REP-17-0754.

\section{Cholinergic input}

In addition to its potential effect in ciliated cells (see 'Luminal fluid and sperm transport' section), cholinergic signaling also mediates smooth muscle contractions in vitro and in vivo (Laitinen \& Talo 1981, Pholpramool \& Triphrom 1984, Siu et al. 2006). M3 mAChRs were found in the smooth muscle layer of the rat epididymal duct, mainly in the cauda (Siu et al. 2006).

Despite of many experimental studies, the functional relevance of the cholinergic input on contractions of the epididymal duct is unclear. Still, it is assumed that adrenergic innervation is more potent.

\section{Nerve injury and experimental denervation}

A neuronal input certainly contributes to the coordinated function of the epididymal smooth muscle, but in men suffering from spinal cord injury, impaired fertility in the majority of patients seems to be rather associated with ejaculatory and erectile dysfunction as well as secretory dysfunction of male accessory sex glands, while there is no evidence for specific deficits of sperm maturation and transport along the length of the epididymis (Brackett et al. 2010, Brackett 2012, Ibrahim et al. 2016). Data from a sympathectomy rat model also suggest intact epididymal function and sperm isolated from the

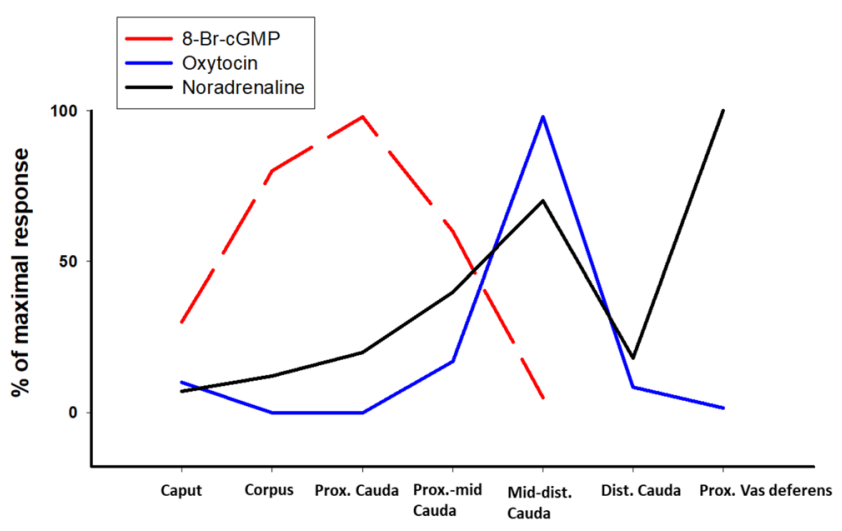

Figure 3 Stimulating effects of oxytocin and noradrenaline on spontaneous contractility as well as relaxing effects of cGMP on the bovine epididymal duct and proximal vas deferens. Colored lines illustrate maximal and minimal response to oxytocin (blue) and noradrenaline (black) (in percent of contraction) along the different epididymal regions. Data were normalized to the respective maximum effects in the mid-dist. cauda. The red line represents relaxing effects of the membrane-permeable cGMP analog 8-Br-cGMP on spontaneous contractility of the epididymal duct and has its greatest impact in the corpus und proximal cauda. Oxytocin and noradrenaline have clearly distinct contractile effects. While oxytocin has its peak effect in the mid-distal cauda, noradrenaline has a relatively weaker effect in this region and elicits its maximum response in the distal cauda. We suggest a function of noradrenaline in ejaculation while oxytocin ensures anterograde flow of sperm.

epididymal cauda showed normal fertilizing capacity (Kempinas et al. 1998). However, it remains to be elucidated in how far potential dysfunction of the distal cauda is also involved in the described disturbances of emission/ejaculation in case of nerve injury and experimental denervation.

\section{Regulation by hormones}

Androgens pididymal function is well known to be androgen dependent. Testosterone produced by testicular Leydig cells is reduced in the epididymis by 5-alpha reductase to dihydrotestosterone (Robaire \& Hinton 2015). Temporary deletion of the Leydig cells by ethane dimethane sulfonate revealed reduced volume of the epididymis and epididymal duct (Yang et al. 2006) potentially suggesting impaired sperm transport.

Presence of classical androgen receptors (ARs) in the epididymis has been intensively investigated in many species (Robaire \& Hinton 2015). Beside epithelial cells, AR was repeatedly described in SMCs of the epididymal duct (Zhou et al. 2002, Trybek et al. 2005) indicating transcription-based testosterone effects in these cells. This might explain long-term effects of androgen (or androgen withdrawal) on contractility (Hib \& Ponzio 1977, Din-Udom et al. 1985) most likely due to changes of cellular signaling or structure. Differences between efferent duct ligation (no lumicrine (Hinton et al. 2000) 
effects) and bilateral castration (neither lumicrine nor systemic effects) are of interest (Din-Udom et al. 1985).

As far as we know, the phenotype of various mouse models with deletion of the AR in SMCs has not yet been investigated in the epididymis different to the testis (Welsh et al. 2009) and prostate (Welsh et al. 2011). Corresponding epididymis data would improve our knowledge of direct androgen effects in epididymal SMCs. Deletion of AR in principal cells of the proximal epididymis resulted in obstructive azoospermia (Krutskikh et al. 2011). However, a possible contribution of SMCs in this process is unclear.

Castration (although not proving direct effects on SMCs) was shown to result in spontaneous contractions in the normally quiescent vas deferens (MacDonald \& McGrath 1980, Johns et al. 1983, Burnstock \& Verkhratsky 2010). Data clearly showing comparable results in the distal epididymis, likewise quiescent, seem to be missing. However, increased contraction amplitudes in caput and corpus as well as increased basal intraluminal pressure in corpus and cauda were described after castration (Din-Udom et al. 1985) suggesting that testosterone has relaxing effects on epididymal smooth muscle.

There are only few studies describing rapid effects of androgen on epididymal contractility. In guinea pig, testosterone was shown to stimulate spontaneous contractions of isolated duct segments within $60 \mathrm{~min}$ (da Silva e Souza et al. 1974). Most likely, such effects are not mediated by classical ARs. Instead, steroid actions via G protein-coupled plasma membrane receptors, also suggested for the epididymis (Robaire \& Hamzeh 2011) or cation channels as described for progesterone in spermatozoa (Lishko et al. 2011, Strünker et al. 2011) are thinkable.

Estrogens In addition to a testicular origin (Hess et al. 2011), estrogen might also be produced locally in the epididymis, since aromatase was shown to be expressed in various epididymal structures (Hess et al. 2011, Oliveira et al. 2012).

Classical estrogen receptors (ESRs) were described in the epididymis of different species and primarily found in the epithelium (Hess et al. 2011, Rago et al. 2018), but also in SMCs (Oliveira et al. 2012, Rago et al. 2018). Regional differences of ESR1 expression are suggested to induce varying estrogen effects along the epididymis (Hess et al. 2011). Apparently, estrogen influences a calcium-sensitizing RhoA/Rho kinase pathway in SMCs of the epididymis, possibly resulting in an increase of contractility (Fibbi et al. 2009). ESR1-KO mice showed disturbed fluid resorption in the efferent ducts resulting in male infertility (Hess et al. 1997). In contrast, aromatase-knockout mice did not show such defects of the efferent ducts (Toda et al. 2008). Blocking the activity of aromatase resulted in changes of endothelin- 1-dependent contractions mediated by oxytocin (Filippi et al. 2005).

Different to androgens, studies directly describing rapid effects of estrogen on contractility of the epididymal duct are missing. G protein-coupled ESRs as binding sites in a non-classical signaling pathway of estrogen were described in epithelial cells of the rat corpus and cauda and suggested to play a role in sperm maturation (Martinez-Traverso \& Pearl 2015). Recent findings in the human proximal epididymis, however, revealed G protein-coupled ESRs not only in epithelial cells, but also in the smooth muscle layer (Rago et al. 2018) pointing to the existence of rapid effects on SMC contractility also by estrogen.

Oxytocin and vasopressin Oxytocin receptors (OTRs) are membrane receptors which transduce rapid effects (Leng \& Sabatier 2017). OTRs were found in the SMC layer of the epididymal duct (Whittington et al. 2001, Mewe et al. 2007). In response to oxytocin epididymal contractions increased in vitro (Hib 1974, Studdard et al. 2002, Filippi et al. 2005) and in vivo (Melin 1970). Unexpectedly, oxytocin has opposite effects in the different regions of the organ and showed relaxing effects in corpus and proximal cauda (Mewe et al. 2007). Relaxing effects were suggested to be epitheliumdependent, since epithelium-denuded corpus segments showed contractile effects (Mewe et al. 2007). Maximum contractile response to oxytocin was found in the midcauda comparable to noradrenaline (Fig. 3). This may be useful for a selective emptying of the cauda during emission. Reduced contractile effects of adrenaline and oxytocin in the distal cauda might ensure an orthograde sperm transport (Mewe et al. 2007).

Vasopressin, a peptide hormone and potent vasoconstrictor, also stimulated epididymal duct SMCs and enhanced contractility of caput and cauda epididymidis (Jaakkola \& Talo 1981, Studdard et al. 2002).

Oxytocin and vasopressin are nonapeptides that differ only in two amino acids. Especially in high concentrations vasopressin can also bind to the OTR and vice versa (Song \& Albers 2017). Therefore, it is necessary to always consider vasopressin when observing oxytocin effects. Using the selective OTR agonist xOT, Mewe and colleagues could mimick contractile oxytocin effects in the bovine duct, pointing to OTRs as main mediators of the observed oxytocin effects (Mewe et al. 2007).

\section{Relevance of the epithelium for contractility}

Mewe et al. (2006a) removed the epithelium of proximal parts of the bovine duct and observed a quiescent duct without contractions. After addition of endothelin-1 or noradrenaline contractions could be induced. However, only prostaglandin (PG) F2a (see below, 'Prostaglandins')-induced phasic activity similar to the 
profile of spontaneous contractions in the intact duct (Mewe et al. 2006b).

While experimental data support a role for various epithelial factors (see below) in regulating epididymal contractile function their overall significance in vivo is less clear and warrants further exploration.

Endothelin-1Endothelin-converting enzyme 1 and the peptide endothelin-1 were detected in the epididymis (Peri et al. 1997). Reappearing contractions induced by endothelin-1 after removal of the epithelium (Mewe et al. 2006b), see above) points to an epithelial source of this peptide. Its receptors $\mathrm{ET}_{\mathrm{A}}$ and $\mathrm{ET}_{\mathrm{B}}$, localized to the SMC layer, were shown to influence these contractions (Peri et al. 1997). Spontaneous contractions of the epididymal duct were discussed to be mediated by a paracrine loop between endothelin-1 and oxytocin ((Filippi et al. 2005) see 'Regulation by hormones' section).

eNOS Mewe and colleagues described the expression of endothelial nitric oxide (NO) synthase (eNOS), one of the three NO synthase (NOS) isoforms (Fig. 4) (Knowles \& Moncada 1994), see 'NO/cGMP' section), in the bovine epididymis as a modulator for spontaneous phasic contractions (Mewe et al. 2006a). eNOS was not only detected in endothelial cells, but also in SMCs and epithelial cells of the epididymal duct (Mewe et al. 2006a). As shown for the vasculature (Busse \& Fleming
1998), a mechanism of stretch-induced eNOS activation and subsequent relaxation is also thinkable for the epididymal duct. The maximum relaxing potency of NO (cGMP) pathways (see 'NO/cGMP' section) was found in the corpus region of the epididymal duct (Fig. 3) different to oxytocin and noradrenaline effects (Mewe et al. 2007). Stretch would be induced by the local luminal sperm content resulting in circumscribed SMC relaxation of the duct at the same position to improve sperm maturation.

Serotonin Beside its role as a monoamine neurotransmitter, serotonin was found in the caput epididymidis and could be detected in epithelial cells (in addition to mast cells and neuroendocrine cells) (Jimenez-Trejo et al. 2007). Immunoreactivity was also observed for serotonin transporter and receptors (Leung et al. 1999, Jimenez-Trejo et al. 2007). While serotonin responses of SMC contractions in the prostate (Killam et al. 1995) and vas deferens (Hay \& Wadsworth 1982) were reported, the role of (epithelial) serotonin in epididymal contractions remains unclear.

Angiotensin Binding sites for angiotensin II were shown from caput to cauda epididymidis and localized to the epididymal duct by receptor autoradiography (Grove \& Speth 1989). Angiotensin II affected expulsions of spermatozoa in the cauda (Grove \& Speth 1989) and

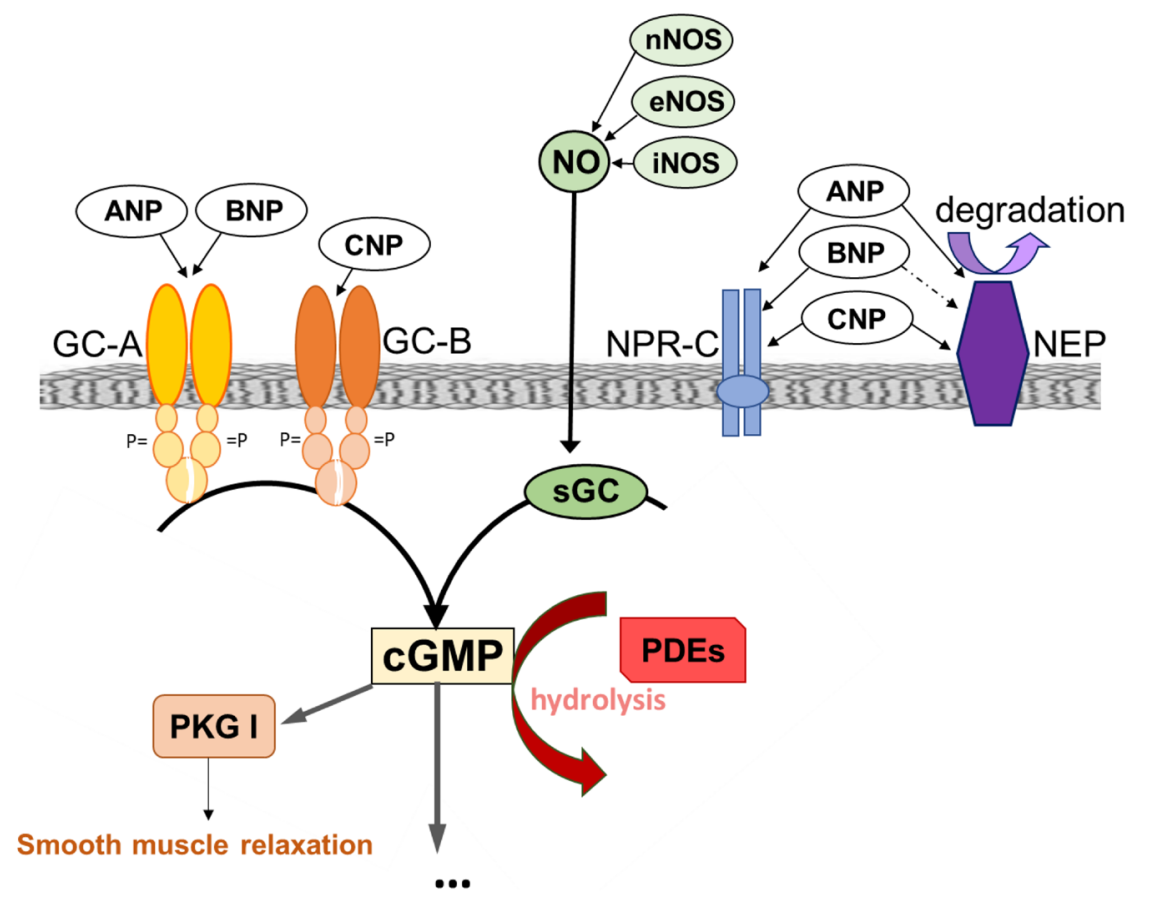

Figure 4 cGMP pathways induce smooth muscle relaxation. Relaxation of smooth muscle cells is predominantly mediated by cGMP signaling and components of this pathway are found within the male reproductive tract. The messenger molecule cGMP is generated by the soluble guanylyl cyclase sGC and different membrane-bound guanylyl cyclases (e.g. GC-A, GC-B). Nitric oxide (NO), generated by $\mathrm{NO}$ synthases (nNOS, eNOS, iNOS), activates sGC. Atrial natriuretic peptide (ANP) and B-type natriuretic peptide (BNP) activate GC-A. C-type natriuretic peptide (CNP) is the ligand of GC-B. Activity of GC-A and GC-B is modulated by at least three different mechanisms: 1 . Degradation of the natriuretic peptides by the neutral endopeptidase (NEP) at the cell surface. 2. Metabolic clearance of the natriuretic peptides by internalization after binding of peptides to the natriuretic peptide clearance receptor (NPRC). 3. Desensitization of GC-A and GC-B by intracellular de-phosphorylation of the receptors. In addition to GC-A and GC-B there are further membrane-binding GCs (not shown). The key enzyme of cGMP-mediated SMC relaxation is cGMP-dependent protein kinase I (PKGI). The duration of a given cGMP signal depends on the activity of different phosphodiesterases (PDEs) which hydrolyze cGMP (and/or cAMP). 
induced contractions in the vas deferens mediated by angiotensin receptor 1 (Sum \& Cheung 1995, Ban et al. 2002). Data on contractile effects in the proximal regions of the epididymal duct are less defined. Angiotensinconverting enzyme (ACE), responsible for cleaving active angiotensin II from the prehormone angiotensin I, was found in epididymal epithelial cells and in high concentration in seminal plasma (Kryukova et al. 2015). Mice lacking (somatic) ACE or angiotensinogen showed normal fertility (Hagaman et al. 1998).

Prostaglandins PGs are synthetized from arachidonic acid by cyclooxygenase (COX)- 1 or -2 in almost every nucleated cell. In the rat epididymis, for example, basal cells of the epithelium were described to contain COX-1 and to secrete PGE2 and PGD2. COX-2 was found in principal cells (Wong et al. 1999). PGs are synthetized as needed and, with a short half-life, suitable as regional messengers of limited duration. Whereas COX-2 was found in the proximal parts of the rat epididymis (but not in the cauda) (Stanfield \& Khan 2003), Lazarus and colleagues (Lazarus et al. 2002) localized the enzyme in the mouse to the distal cauda. COX-1 was described in all parts of the mouse epididymis and increased from caput to cauda (Lazarus et al. 2002). PGD2, PGE1, PGE2 and PGF2alpha were found to be active in the epididymis (Bartke \& Koerner 1974, da Silva e Souza et al. 1975, Hib \& Oscar 1978, Cosentino et al. 1984, Sorrentino et al. 1998). At least in part, their local concentration was influenced by androgens (Bartke \& Koerner 1974). Beside direct effects on contractility, PGs were also suggested to modify the action of neurotransmitters and hormones such as noradrenaline and acetylcholine (da Silva e Souza et al. 1975, Hib \& Oscar 1978).

Interestingly, the function of the single PGs might differ. Cosentino et al. (1984) reported increasing contractions after addition of PGF2alpha to the isolated rat caput epididymidis, whereas PGE2 had an opposite effect (Cosentino et al. 1984). In the isolated cauda epididymidis of the guinea pig, PGE1, PGE2 and PGF2alpha showed stimulating effects on contractility (da Silva e Souza et al. 1975). Increasing contractility was also observed by Hib and Oscar (1978) who infused PGE2 and PGF2alpha systemically (Hib \& Oscar 1978).

\section{Influence of sperm/luminal factors in contractility of the epididymal duct}

While the influence of epithelial cells on smooth muscle contractions is conceivable by their direct neighborhood, it is noteworthy that luminal factors or sperm can also modify contractile activity as shown by Mewe et al. who demonstrated spontaneous burst-like phasic contractions instead of regular phasic contractions after rinsing the lumen of sperm and other luminal factors (Mewe et al. 2006b).

\section{Influence of elements of the SMC layer on contractions of the epididymal duct}

Interstitial cells of Cajal Interstitial cells (ICCs) of Cajal (1911) function as pacemakers for SMCs and are found throughout the gastrointestinal tract. Their occurrence has also been suggested in the genitourinary tract (Lang et al. 1998). In the bovine epididymal duct, 'atypical muscle cells' with cytoplasmic extensions may represent epididymal ICCs (Mewe et al. 2006b). The $\mathrm{Ca}^{2+}$-activated chloride channel TMEM16A is known to be involved in spontaneous SMC contractility and was found in ICCs (but not in typical SMCs) of the gastrointestinal tract. Thus, TMEM16A-positive epididymal cells could indicate ICCs (Huang et al. 2009). Most recently, TMEM16 was suggested to be also functionally active in epididymal epithelial cells (Gao et al. 2016). In these cells, TMEMA16 is coupled to the $\mathrm{Ca}^{2+}$ channel TRPV6. Interestingly, pore mutation or knockout of TRPV6 (Weissgerber et al. 2011, 2012) leads to severe defects of $\mathrm{Ca}^{2+}$ absorption in the epididymal duct resulting in male infertility.

\section{Relaxation of SMCs regulated by cGMP signaling NO/CGMP}

Relaxation of SMCs is predominantly mediated by cyclic guanosine monophosphate (cGMP) signaling and components of this pathway are found within the male reproductive tract. The messenger molecule cGMP is generated by either soluble (cytosolic) guanylyl cyclase (sGC) or membrane-bound particulate guanylyl cyclases (pGC, e.g. GC-A, GC-B, Fig. 4) (Kuhn 2016). In the epididymis, sGC is - apart from certain epithelial cells (Shum et al. 2008) - mainly expressed in SMCs of the epididymal duct (Mewe et al. 2006a, Mietens et al. 2012) and mediates its relaxing effects when stimulated by NO (Mewe et al. 2006a). NO effects were prevented by prior application of the sGC blocker ODQ (Mewe et al. 2006a) showing that the action of the NO donor is dependent on CGMP synthesis. NO is generated by the constitutive NOS isoforms neuronal (nNOS) and eNOS (see 'Relevance of the epithelium for contractility' section) as well as inducible NOS (iNOS) (Fig. 4) (Knowles \& Moncada 1994). All isoforms were found within the epididymal duct (epithelium (see 'Relevance of the epithelium for contractility' section), SMC layer) or its direct neighborhood (nerve fibers (see 'Neuronal input' section), blood vessels) (Burnett et al. 1995, Dun et al. 1996, Zini et al. 1996, Wiszniewska et al. 1997, Mewe et al. 2006a), allowing $\mathrm{NO}$ to reach its receptor SGC in the SMC layer of the duct. NOS activity was described in the epididymis of different species. NOS activity was found in all three regions of the rat epididymis (Burnett et al. 1995) and is particularly high in the cauda consistent with a rich supply of nNOS-immunoreactive fibers (Dun et al. 
1996). Inhibition of NOS increased spontaneous contractility of the epididymal duct (Mewe et al. 2006a) and points to a basal activity of NO-generating enzymes. After castration of rats, NOS activity was significantly reduced in all regions of the epididymidis, indicating an involvement of androgen in epididymal NOS activity (Chamness et al. 1995). Especially the NOS/NO/cGMP pathway of SMC relaxation might provide a crucial mechanism to ensure epididymal sperm maturation (see 'Relevance of the epithelium for contractility' section (eNOS) and Fig. 4).

\section{Natriuretic peptides/cGMP}

C-type natriuretic peptide (CNP), the ligand for the pGC GC-B (Fig. 4), exerts local activities (Kuhn 2016) and is abundant in rat and bovine seminal plasma (Chrisman etal. 1993, Hosang \& Scheit 1994). Epididymal epithelial and SMCs produce CNP (Nielsen et al. 2008, Thong et al. 2014) and GC-B was described in turtle (Kim et al. 2000), bovine (Mewe et al. 2006a), human, mouse (Thong et al. 2014) and rat (Müller et al. 2011) epididymis. In agreement with relaxing CNP effects on isolated parts of the bovine epididymal duct (Mewe et al. 2006a), GC-B was shown to be expressed in the wall of the epididymal duct including the SMC layer, both at the mRNA level by laser capture microscopy (LCM) and RT-PCR (Thong et al. 2014) as well as at the protein level (by receptor autoradiography (Mewe et al. 2006a) and immunofluorescence (Thong et al. 2014)).

Atrial natriuretic peptide (ANP) and B-type natriuretic peptide (BNP), which act as hormones in the regulation of blood pressure and fluid volume homeostasis, bind to the pGC GC-A (Fig. 4). GC-A was also shown to be expressed in the bovine and rat epididymis (Mewe et al. 2006a, Müller et al. 2011) and could be localized to ductal SMCs (Mietens et al. 2014). In agreement, ANPand CNP-induced relaxation of the bovine epididymal duct could be prevented by the GC-A/GC-B blocker HS142-1 (Mewe et al. 2006a). Different to bovine tissue, only ANP, but not CNP, resulted in significant relaxing effects in the rat epididymal duct (Mietens et al. 2014), suggesting further, yet undefined functions of CNP/GC-B signaling in the muscle layer of the duct.

Activity of the natriuretic peptide receptors GC-A and GC-B is modulated by at least three different mechanisms (Fig. 4). Availability of the ligands is controlled by the plasma membrane protein neutral endopeptidase (NEP, also known as metallo-endopeptidase EC 3.4.24.11; enkephalinase, neprilysin, CD10, CALLA) (Terawaki et al. 2007) which cleaves and inactivates a variety of biologically active peptides including natriuretic peptides (Corti et al. 2001). By this, NEP regulates the local concentrations of natriuretic peptides at the cell surface (Pankow et al. 2009, Potter 2011). In the epididymis, cleavage of CNP and reduction of CNP-induced CGMP production by NEP was described
(Thong et al. 2014). Another mechanism to control responses to natriuretic peptides is binding to a further natriuretic peptide receptor, the clearance receptor (NPRC), devoid of GC activity, which binds all natriuretic peptides with equal affinity and provides metabolic clearance of the circulating natriuretic peptides by internalization (Potter 2011). Further, activity of GC-A and GC-B is known to be downregulated by intracellular de-phosphorylation of the receptors ('desensitization') (Potter \& Garbers 1992, Müller et al. 2006).

In addition to GC-A and GC-B, there are further membrane-binding GCs. So far, only GC-C, known to be involved in intestinal ion transport and epithelial turnover was also described in epithelial cells of the epididymis (Jaleel et al. 2002). It is not known, however, whether GC-C influences local smooth muscle contractility.

\section{cGMP-dependent protein kinases}

The key enzyme of cGMP-mediated SMC relaxation is cGMP-dependent protein kinase I (PKGl, Fig. 4) (Hofmann \& Wegener 2013) that was detected in all parts of bovine and rat epididymal duct using immunoblotting (Mewe et al. 2006a, Müller et al. 2011) and crosslinking experiments with fluorescein-coupled cGMP (Mewe et al. 2006a,b). Interestingly, in the aging epididymis, a significant decrease of PKGI expression was found (Müller et al. 2011). Immunohistochemical analyses revealed the kinase in the muscle wall of the epididymal duct and also in some epithelial cells (Mewe et al. 2006a).

The inhibitory effect of the membrane-permeable cGMP analog 8-Br-cGMP on contractions of the epididymal duct was clearly reduced by the PKG inhibitor Rp-8-Br-cGMPS as well as by iberiotoxin, thapsigargin and indomethacin, pointing to PKGI as a main target for cGMP and to large-conductance $\mathrm{Ca}^{2+}$ activated $\mathrm{K}^{+}$channels, the sarcoplasmic endoplasmic reticulum $\mathrm{Ca}^{2+}$-ATPase and COX-1 as possible targets of PKG (Mewe et al. 2006a).

\section{Phosphodiesterases}

The duration of a given cGMP signal depends on the activity of phosphodiesterases (PDEs, Fig. 4). They hydrolyze the intracellular second messenger and thereby control cGMP levels (Bender \& Beavo 2006). Among the 11 families of PDEs described so far, PDEs differ in their substrate specificity and are able to hydrolyze cGMP (PDE5, PDE6, PDE9), cAMP (PDE4, PDE7, PDE8) or both cyclic nucleotides (PDE1, PDE2, PDE3, PDE10, PDE11), thus mediating a possible crosstalk between these two second messenger systems (Bender \& Beavo 2006).

PDE5 was exclusively localized to the SMC layer of the human and rat epididymal duct, both at the mRNA level by LCM in combination with RT-PCR and at the protein 
level by immunoblotting and immunohistochemistry (Müller et al. 2011, Mietens et al. 2012). In contrast, there was no evidence for PDE5 expression in the epididymal epithelium (Mietens et al. 2012). The PDE5 inhibitor sildenafil interfered with epididymal cGMP degradation in vitro (Mietens et al. 2012), and with contractility of the rat epididymal duct ex vivo, as shown by contraction force recordings (Mietens et al. 2012) and time-lapse imaging (Mietens et al. 2014).

The non-specific PDE inhibitor isobutyl methyl xanthine (IBMX), which inhibits most of the PDEs described so far (Lugnier 2006), blocked most of the CGMP-degrading activity of epididymal protein fractions. In the epididymal duct IBMX resulted in a more pronounced reduction of contractions compared to PDE5 inhibitors, suggesting expression of further yet undefined PDEs that might affect contractility in the epididymal duct. In agreement, transcripts of PDE1, PDE2 and PDE3 were detected in the smooth muscle layer of the rat epididymis (our unpublished results). The absence of PDE3A and PDE3B in the corresponding human probes (Fig. 5) points to species-specific differences in the epididymal expression of cGMP pathway components. The existence of other PDEs than PDE5 is also implied by the finding that relatively small amounts of the cGMP-hydrolyzing PDE5 are expressed in rat epididymis compared to large amounts of the cGMPgenerating sGC, GC-A and GC-B (Müller et al. 2011).

\section{Contractility and infertility}

\section{Epididymitis: aspects of contractility}

Investigations of pathological processes in the epididymis resulting in male infertility are of high interest. In this context, epididymitis was recently reviewed (Michel et al. 2015, Taylor 2015), but data on the smooth muscle layer of the epididymal duct and possible alteration in case of epididymitis are nearly completely missing. Interestingly, a mouse model of ascending infection with uropathogenic E. coli (UPEC) showed a decrease of the ductal diameter in upstream segments 3 days after infection (Stammler et al. 2015) suggesting infection-induced effects on SMC contractility. After 7 days of infection in the same UPEC mouse model, ductal obstruction in the infected region was described (Michel et al. 2016). In human chronic epididymitis, similar obstructive changes of the duct were observed (Stammler et al. 2015, Michel et al. 2016). These findings indicate that infection and inflammation also target structure and function of epididymal SMCs.

\section{Molecular mechanisms: lessons from the vas deferens}

So far, male infertility cannot be related to the absence or mutation of single molecules that affect contractility of the epididymal duct. In the vas deferens, however, specific molecules impairing contractility were shown to be crucial for male fertility.

\section{Purinergic signaling}

Knockout of the purinergic P2X1 receptors, for example, reduced male fertility by $90 \%$ (Mulryan et al. 2000) and in a double knockout model of the frequently co-expressed P2X1 receptor and alpha1-adrenergic receptor (Ventura \& Pennefather 1991), vas deferens contractions were disrupted and resulted in male infertility (White et al. 2013). P2X1 receptors are ATP-gated cation channels

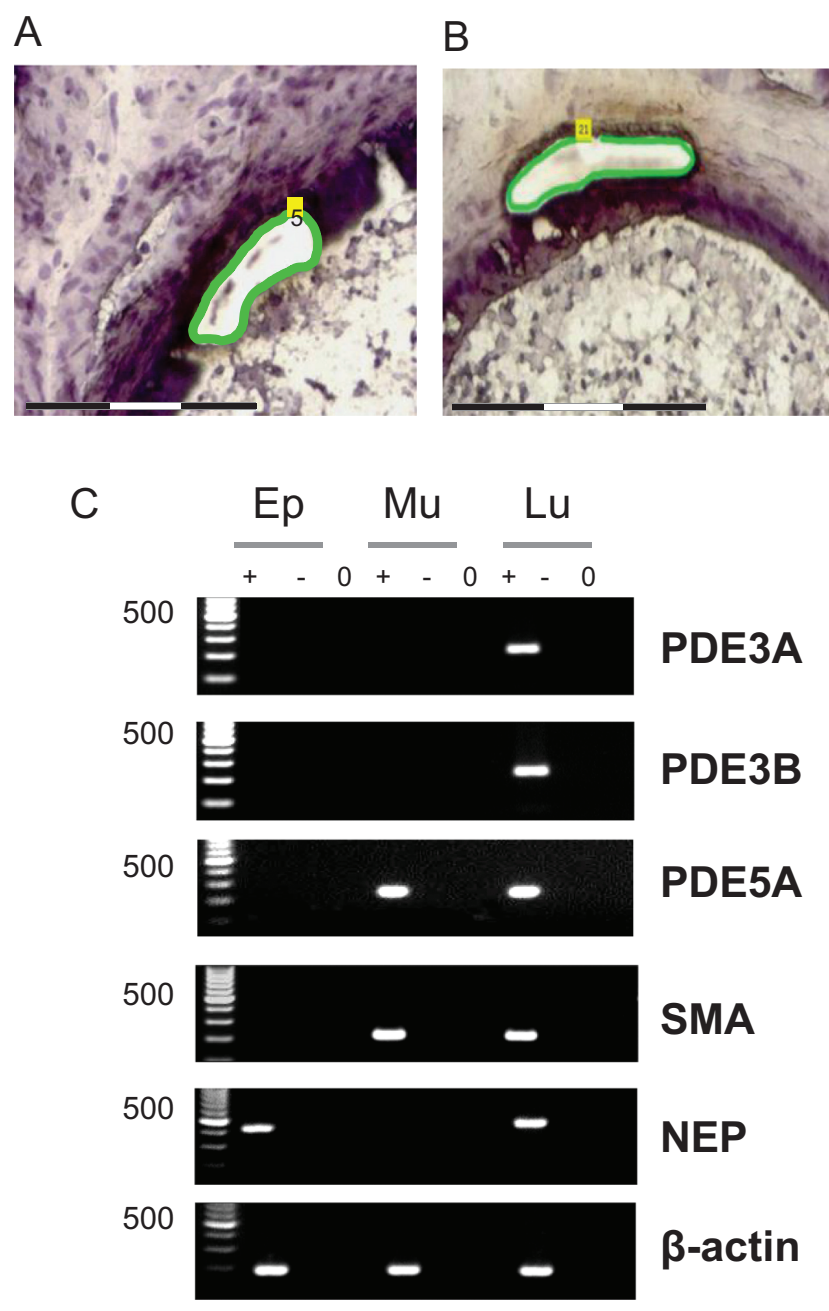

Figure 5 Expression and localization of specific PDEs in human epididymis. (A and B) Laser-assisted microdissection combined with (C) RT-PCR analysis of PDE3A (236 bp), PDE3B (242 bp) and PDE5A (245 bp) of isolated epithelial cells (Ep) and SMCs of the human epididymis. SMA marks SMCs (140 bp) and NEP (411 bp) identifies epithelial cells. Lung tissue (lu) and (amplification of) the housekeeping gene beta-actin (199 bp) served as a positive control. ' $+{ }^{\prime},{ }^{\prime}-$ ' and ' 0 ' represent lanes with reverse transcriptase, without reverse transcriptase and water control. PDE3A and PDE3B could not be detected in isolated epithelial cells and SMCs. PDE5A was only detected in SMCs. (Data and figure: courtesy by Dr Caroline Feuerstacke.) 
regulating $\mathrm{Ca}^{2+}$ influx, which mediates vas deferens contractions upon sympathetic nerve stimulation (Lee et al. 2000). Additionally, P2X1 and P2X2 receptors were identified in the epididymal SMC layer (Lee et al. 2000). Interestingly, purinergic signaling seems to have differential effects on longitudinal vs circular SMCs in the vas deferens (Amobi et al. 2012). It is currently unknown if a similar differential regulation occurs in the cauda epididymidis, which also shows an outer longitudinal SMC layer (Baumgarten et al. 1971). It is conceivable that $\mathrm{P} 2 \mathrm{X}$ receptors contribute to the regulation of both, epididymal contractility and sperm release from the cauda. Purinergic signaling may be further modulated by NTPDase1, an extracellular ectonucleotidase, which was found in the tunica muscularis of the vas deferens (Kauffenstein et al. 2014). The absence of NTDPase1 leads to an enhanced contractile response to extracellular ATP in the vas deferens, desensitization of the P2X1 receptor and reduced receptor protein expression (Kauffenstein et al. 2014). Both, NTPDase1 and 2, are also expressed in epididymal SMCs (MartínSatué et al. 2009).

\section{Alpha1-adrenergic signaling}

In alpha1-adrenergic receptor-knockout mice (Sanbe et al. 2007), reduced contractions of the vas deferens were reported. Deletion of one of the three subtypes (alpha1A) markedly decreased contractions while in triple (1A, 1B, 1D) KO mice, vas deferens contractions were completely eliminated resulting in reduced sperm content in the ejaculate and reduced pregnancy rate (Sanbe et al. 2007). Until now it remains unknown whether contractions of the cauda epididymidis are similarly affected in these mouse models and in how far epididymal effects contribute to the described effects on fertility.

\section{NPY}

In men and various mammals, high levels of NPY were found in noradrenergic nerves supplying the muscle layer of the vas deferens (Lundberg et al. 1983, Jen et al. 1997). NPY inhibited the contractile response to electrically evoked field stimulation (Allen et al. 1982). In the epididymis, however, NPY had no effect on field stimulation-induced contractions of the isolated duct of the cauda region. It was suggested that NPY has postjunctional actions, which mask its pre-junctional effects (Haynes et al. 1997).

\section{VIP}

In the vas deferens, vasoactive intestine polypeptide (VIP) inhibited electrically induced contractions. Investigations on the presence of VIP in the epididymis of the guinea pig showed an exclusive localization in the caudal parts and especially in the SMC layer
(Kastin et al. 1978, Greenberg et al. 1985) suggesting a role of VIP on relaxation to improve sperm storage. However, functional studies in the epididymis are necessary to confirm this hypothesis. Moreover, VIP- but not tyrosine hydroxylase-positive fibers were described to co-express nNOS (Dun et al. 1996).

\section{NOS and acetylcholine}

Regarding the cholinergic system of the vas deferens, it was found that cholinergic nerve fibers were less abundant than adrenergic ones and preferentially reach the lamina propria (for review, Koslov \& Andersson 2013). Around 50\% of VAChT-positive fibers also contained NOS (Dixon et al. 2000). Unpublished data of our group, investigating the epididymal duct in the rat cauda, suggest that cholinergic effects result in smooth muscle relaxation mediated by NOS.

\section{Potential side effects of medications}

Male infertility may be related to disorders of spermatogenesis, post-testicular sperm maturation or sexual function ensuring ejaculation of spermatozoa. The impact of drugs on male fertility has recently been reviewed (Semet et al. 2017), but still, data on drug effects or side effects on epididymal contractility is sparse. Medications that target smooth musculature potentially interfere with epididymal contraction and thus could prevent the correct maturation and transport of sperm. A range of drugs in clinical use might affect contractility of the epididymal duct.

\section{Nonsteroidal anti-inflammatory drugs}

Nonsteroidal anti-inflammatory drugs (NSAIDs) interfere with PG synthesis (see 'Influence of sperm/ luminal factors in contractility of the epididymal duct' section) and could alter local smooth muscle function. Indomethacin, an example for NSAIDs, was reported to reduce epididymal contractility (da Silva e Souza et al. 1975) and to inhibit responses to noradrenaline or acetylcholine (Hib \& Oscar 1978). Different NSAIDs are widely used as analgetics and acetyl salicylic acid is additionally used to inhibit platelet aggregation. Possible side effects on male fertility are, however, largely unknown.

\section{PDE inhibitors}

Drugs interfering with PDEs (see 'Phosphodiesterases' section) are gaining importance in different clinical fields and potential side effects of PDE inhibitors are conceivable.

Toxicity related to PDE4 inhibitors was reported in rat epididymis with dilatation of efferent ducts and the initial segment followed by the formation of sperm granulomata in caput and cauda of the epididymis (Heuser et al. 
2013). PDE4 inhibitors are currently developed for the treatment of inflammatory diseases like asthma, chronic obstructive pulmonary disease (COPD) (Rabe 2011), rheumatoid arthritis and psoriasis (Pagès et al. 2009, Sakkas et al. 2017, Torres \& Puig 2017). With apremilast approved for the treatment of psoriasis, and roflumilast used in COPD treatment, PDE4 inhibitors are already in clinical use.

PDE5 inhibitors like sildenafil, tadalafil or vardenafil are used in the treatment of erectile dysfunction (SmithHarrison et al. 2016), but also to treat pulmonary hypertension (Ghofrani etal. 2006) thereby exposing more and younger patients. Interestingly, long-term treatment with sildenafil did not change spontaneous contractility of the epididymis in a rat model (Mietens et al. 2014). Tadalafil, gaining additional importance for the treatment of benign prostatic hyperplasia (BPH), was not tested in that study.

Further PDE inhibitors may be of importance in the future. PDE10 inhibitors are under development to treat psychiatric and neurological disorders (Chappie et al. 2009, Abdel-Magid 2013). PDE2 represents an interesting target for psychiatric, cognitive (Abdel-Magid 2017, Zhang et al. 2017) and cardiovascular (Bobin et al. 2016) diseases and PDE3 inhibitors are used in acute therapy for heart failure (Movsesian 2016). Regarding potential side effects on epididymal contractility, it is of interest that PDE3 seems to be missing especially in the human epididymis (see 'Phosphodiesterases' section and Fig. 5).

\section{Nitrates/NO-releasing drugs}

Also of widespread use in the treatment of coronary artery disease are substances like nitrates (e.g. ISDN, ISMN, molsidomine), which release $\mathrm{NO}$ (see $\mathrm{NO} /$ cGMP' section and Fig. 4). We could demonstrate the importance of the NO/cGMP signaling system for the regulation of spontaneous epididymal contractility in rat (Mietens et al. 2012, 2014) and bull (Mewe et al. 2006a, 2007).

\section{Adrenergic receptor antagonists and agonists}

Alpha-adrenergic as well as cholinergic pathways have been shown to be functional in the regulation of epididymal contractility (Chaturapanich et al. 2002). Many drugs in clinical use that interfere with these signaling pathways may therefore alter epididymal sperm transport and maturation.

Alpha1-adrenergic receptor antagonists like tamsulosin or silodosin are in clinical use for the management of BPH (Fibbi et al. 2009, Gacci et al. 2016). While adverse effects on vas deferens contractility with ejaculatory disorders were reported in men (Kobayashi et al. 2008), data on epididymal effects are only available from rat (Chaturapanich et al. 2002) and bovine (Mewe et al. 2006b) models.
Alpha1-adrenergic receptor antagonists like prazosin, doxazosin or terazosin are also used to treat arterial hypertension.

Clonidine, an alpha2-adrenergic receptor agonist (see 'Neuronal input' section), used to lower blood pressure was shown to enhance epididymal contractility and to alter sperm parameters in the rat (da Silva Júnior et al. 2014).

In contrast to alpha-adrenergic signaling, betaadrenergic influence seems not to affect epididymal contractility (Chaturapanich et al. 2002), but in a rat model, reversible histologic changes were reported during administration of beta-adrenergic blockers (el-Sayed et al. 1998).

\section{Psychotropic drugs}

Psychotropic medications like anti-depressants or anti-psychotics interfere with various signaling, thus, unwanted effects on epididymal contractions are likely, but remain largely unknown. An inverse stimulating effect on epididymal contractility with reduced sperm count and quality was reported for drugs like sibutramine, an appetite suppressant (Borges et al. 2013) or bupropion used for smoking cessation and as an antidepressant (Cavariani et al. 2015). The drugs interfere with the re-uptake of noradrenaline and dopamine thereby modulating these signaling systems with potential side effects on epididymal contractility.

\section{Anti-cholinergic drugs}

Cholinergic signaling at the level of the epididymis could be disturbed by drugs that have anticholinergic side effects like anti-depressants. Such drugs are usually given over longer time periods.

Inhaled atropine, an anticholinergic that is used as a bronchodilator, may rather have local effects in the respiratory system. In the rat, effects of anti-muscarinic drugs were associated with reduced fertility, but effects on the epididymis were not clearly discriminated from effects on other organs in the male reproductive tract; however, adverse effects seem to recede with discontinuation of the treatment (Ban et al. 2002).

\section{$\mathrm{Ca}^{2+}$ antagonists}

$\mathrm{Ca}^{2+}$ antagonists, such as nifedipin, are established in the treatment of hypertension, for their relaxing effect on vascular SMCs. Side effects on the SMC layer of the epididymal duct are well conceivable, but compared to the vas deferens (Blakeley et al. 1981), the epididymis was barely investigated.

\section{ACE inhibitors}

The epididymal lumen seems to be protected from ACE inhibitors, established in the treatment of arterial hypertension, by the blood-epididymis barrier 
(Wong \& Uchendu 1990), but side effects mediated by SMCs are possible (see 'Relevance of the epithelium for contractility' section).

\section{Interference with androgens}

Androgen effects on epididymal contractility (see 'Regulation by hormones' section) may be disturbed by the 5-alpha reductase (see 'Regulation by hormones' section) inhibitor finasteride used in BPH treatment. In a rat model, this drug caused decreased male infertility (Robaire \& Henderson 2006).

\section{Conclusion}

Currently, our knowledge about the molecular mechanisms orchestrating epididymal contractions and transport processes is still limited as is our insight into potential side effects of pharmacologic treatment. Thus, further studies are needed to better explore and define the role of the epididymis for male infertility.

\section{Declaration of interest}

The authors declare that there is no conflict of interest that could be perceived as prejudicing the impartiality of this review.

\section{Funding}

This work was supported by the Deutsche Forschungsgemeinschaft (DFG, Germany), with grant KFO 181 and as part of an International Research Training Group project (GRK 1871/1, P6). Funding was also received from the University Hospital Giessen and Marburg.

\section{Acknowledgements}

The authors are most grateful to Christina Seidel who contributed Fig. 2 and Video 1 and to Dr Caroline Feuerstacke who contributed the data presented in Fig. 5. Excellent technical support by Sabine Tasch, Ingrid Schneider-Hüther and Andre Kaschtanow is also greatly appreciated. Moreover, they thank Prof. Hans-Christian Schuppe for fruitful discussions.

\section{References}

Abdel-Magid AF 2013 PDE10 inhibitors as potential treatment for schizophrenia. ACS Medicinal Chemistry Letters 4 161-162. (https://doi. org/10.1021/ml4000194)

Abdel-Magid AF 2017 Potential treatment of cognitive impairment in schizophrenia by phosphodiesterase 2 (PDE2) inhibitors. ACS Medicinal Chemistry Letters 8 17-18. (https://doi.org/10.1021/ acsmedchemlett.6b00514)

Allen JM, Adrian TE, Tatemoto K, Polak JM, Hughes J \& Bloom SR 1982 Two novel related peptides, neuropeptide $Y(N P Y)$ and peptide $Y Y$ (PYY) inhibit the contraction of the electrically stimulated mouse vas deferens. Neuropeptides 3 71-77. (https://doi.org/10.1016/01434179(82)90001-4)
Amann RP \& Howards SS 1980 Daily spermatozoal production and epididymal spermatozoal reserves of the human male. Journal of Urology 124 211-215. (https://doi.org/10.1016/S0022-5347(17)55377-X)

Amobi NIB, Guillebaud J \& Smith ICH 2012 Perspective on the role of P2X-purinoceptor activation in human vas deferens contractility. Experimental Physiology 97 583-602. (https://doi.org/10.1113/ expphysiol.2011.063206)

Ban Y, Sato T, Nakatsuka T, Kemi M, Samura K, Matsumoto H, Cukierski MA \& van Zwieten MJ 2002 Impairment of male fertility induced by muscarinic receptor antagonists in rats. Reproductive Toxicology $\mathbf{1 6}$ 757-765. (https://doi.org/10.1016/S0890-6238(02)00050-3)

Bartke A \& Koerner S 1974 Androgenic regulation of the concentration of prostaglandin $\mathrm{F}$ in the male reproductive system of rats and mice. Endocrinology 95 1739-1743. (https://doi.org/10.1210/endo-95-61739)

Baumgarten HG, Falck B, Holstein AF, Owman C \& Owman T 1968 Adrenergic innervation of the human testis, epididymis, ductus deferens and prostate: a fluorescence microscopic and fluorimetric study. Zeitschrift für Zellforschung und Mikroskopische Anatomie 90 81-95.

Baumgarten HG, Holstein AF \& Rosengren E 1971 Arrangement, ultrastructure, and adrenergic innervation of smooth musculature of the ductuli efferentes, ductus epididymidis and ductus deferens of man. Zeitschrift für Zellforschung und Mikroskopische Anatomie 120 37-79.

Bender AT \& Beavo JA 2006 Cyclic nucleotide phosphodiesterases: molecular regulation to clinical use. Pharmacological Reviews $\mathbf{5 8}$ 488-520. (https://doi.org/10.1124/pr.58.3.5)

Blakeley AGH, Cunnane TC \& Petersen SA 1981 An electropharmacological analysis of the effects of some drugs on neuromuscular transmission in the vas deferens of the guinea-pig. Journal of Autonomic Pharmacology 1 367-376. (https://doi.org/10.1111/j.1474-8673.1981.tb00075.x)

Bobin P, Belacel-Ouari M, Bedioune I, Zhang L, Leroy J, Leblais V, Fischmeister R \& Vandecasteele G 2016 Cyclic nucleotide phosphodiesterases in heart and vessels: a therapeutic perspective. Archives of Cardiovascular Diseases 109 431-443. (https://doi. org/10.1016/j.acvd.2016.02.004)

Borges CS, Missassi G, Pacini ESA, Kiguti LRA, Sanabria M, Silva RF, Banzato TP, Perobelli JE, Pupo AS \& Kempinas WG 2013 Slimmer or fertile? Pharmacological mechanisms involved in reduced sperm quality and fertility in rats exposed to the anorexigen sibutramine. PLOS ONE 8 e66091. (https://doi.org/10.1371/journal.pone.0066091)

Brackett NL 2012 Infertility in men with spinal cord injury: research and treatment. Scientifica 2012578257.

Brackett NL, Lynne CM, Ibrahim E, OhI DA \& Sønksen J 2010 Treatment of infertility in men with spinal cord injury. Nature Reviews: Urology 7 162-172. (https://doi.org/10.1038/nrurol.2010.7)

Burnett AL, Ricker DD, Chamness SL, Maguire MP, Crone JK, Bredt DS, Snyder SH \& Chang TS 1995 Localization of nitric oxide synthase in the reproductive organs of the male rat. Biology of Reproduction 52 1-7. (https://doi.org/10.1095/biolreprod52.1.1)

Burnstock G \& Verkhratsky A 2010 Vas deferens - a model used to establish sympathetic cotransmission. Trends in Pharmacological Sciences 31 131-139. (https://doi.org/10.1016/j.tips.2009.12.002)

Busse R \& Fleming I 1998 Pulsatile stretch and shear stress: physical stimuli determining the production of endothelium-derived relaxing factors. Journal of Vascular Research 35 73-84. (https://doi. org/10.1159/000025568)

Cajal, SR 1911 Histologie du système nerveux de l'Homme et des vertèbres. Maloine 2 891-942.

Cavariani MM, de Almeida Kiguti LR, de Lima Rosa J, de Araujo Leite GA, Silva PVE, Pupo AS \& de Grava Kempinas W 2015 Bupropion treatment increases epididymal contractility and impairs sperm quality with no effects on the epididymal sperm transit time of male rats. Journal of Applied Toxicology 35 1007-1016. (https://doi.org/10.1002/jat.3089)

Chamness SL, Ricker DD, Crone JK, Dembeck CL, Maguire MP, Burnett AL \& Chang TS 1995 The effect of androgen on nitric oxide synthase in the male reproductive tract of the rat. Fertility and Sterility 63 1101-1107. (https://doi.org/10.1016/S0015-0282(16)57555-4)

Chappie T, Humphrey J, Menniti F \& Schmidt C 2009 PDE10A inhibitors: an assessment of the current CNS drug discovery landscape. Current Opinion in Drug Discovery and Development 12 458-467.

Chaturapanich G, Maythaarttaphong S, Verawatnapakul V \& Pholpramool C 2002 Mediation of contraction in rat cauda epididymidis 
by alpha-adrenoceptors. Reproduction 124 887-892. (https://doi. org/10.1530/rep.0.1240887)

Chrisman TD, Schulz S, Potter LR \& Garbers DL 1993 Seminal plasma factors that cause large elevations in cellular cyclic GMP are C-type natriuretic peptides. Journal of Biological Chemistry 268 3698-3703.

Clulow J, Jones RC \& Hansen LA 1994 Micropuncture and cannulation studies of fluid composition and transport in the ductuli efferentes testis of the rat: comparisons with the homologous metanephric proximal tubule. Experimental Physiology 79 915-928. (https://doi.org/10.1113/ expphysiol.1994.sp003817)

Corti R, Burnett JC, Rouleau JL, Ruschitzka F \& Lüscher TF 2001 Vasopeptidase inhibitors: a new therapeutic concept in cardiovascular disease? Circulation 104 1856-1862. (https://doi.org/10.1161/ hc4001.097191)

Cosentino MJ, Takihara H, Burhop JW \& Cockett AT 1984 Regulation of rat caput epididymidis contractility by prostaglandins. Journal of Andrology 5 216-222. (https://doi.org/10.1002/j.1939-4640.1984.tb02399.x)

da Silva e Souza MC, Gimeno MF \& Gimeno AL 1974 Spontaneous and testosterone-induced motility of isolated guinea-pig cauda epididymis. Experientia 30 1063-1065. (https://doi.org/10.1007/BF01939012)

da Silva e Souza MC, Gimeno MF \& Gimeno AL 1975 Physiologic and pharmacologic studies on the motility of isolated guinea pig cauda epididymidis. Fertility and Sterility 26 1250-1256. (https://doi. org/10.1016/S0015-0282(16)41542-6)

da Silva Júnior ED, de Souza BP, Vilela VV, Rodrigues JQD, Nichi $M$, de Agostini Losano JD, Dalmazzo A, Barnabe VH, Jurkiewicz A \& Jurkiewicz NH 2014 Epididymal contraction and sperm parameters are affected by clonidine. Andrology 2 955-966. (https://doi.org/10.1111/ andr.283)

Davidoff MS \& Middendorff R 2000 Chapter VIII: The nitric oxide system in the urogenital tract. In Functional Neuroanatomy of the Nitric Oxide System, pp 267-314. Elsevier: Amsterdam, The Netherlands.

Davidoff MS, Middendorff R, Enikolopov G, Riethmacher D, Holstein AF \& Müller D 2004 Progenitor cells of the testosterone-producing Leydig cells revealed. Journal of Cell Biology 167 935-944. (https://doi. org/10.1083/jcb.200409107)

Din-Udom A, Sujarit S \& Pholpramool C 1985 Short-term effect of androgen deprivation on intraluminal pressure and contractility of the rat epididymis. Journal of Reproduction and Fertility 73 405-410. (https:// doi.org/10.1530/jrf.0.0730405)

Dixon JS, Jen PY \& Gosling JA 2000 The distribution of vesicular acetylcholine transporter in the human male genitourinary organs and its co-localization with neuropeptide $\mathrm{Y}$ and nitric oxide synthase. Neurourology and Urodynamics 19 185-194. (https://doi.org/10.1002/ (SICI)1520-6777(2000)19:2<185::AID-NAU9>3.0.CO;2-2)

Domeniconi RF, Souza ACF, Xu B, Washington AM \& Hinton BT 2016 Is the epididymis a series of organs placed side by side? Biology of Reproduction $9510 . \quad$ (https://doi.org/10.1095/ biolreprod.116.138768)

Dun NJ, Dun SL, Huang RL, Dun EC, Lai CC, Wong PY \& Forstermann U 1996 Distribution of origin of nitric oxide synthase-immunoreactive nerve fibers in the rat epididymis. Brain Research 738 292-300. (https:// doi.org/10.1016/S0006-8993(96)00795-0)

El-Badawi A \& Schenk EA 1967 The distribution of cholinergic and adrenergic nerves in the mammalian epididymis: a comparative histochemical study. American Journal of Anatomy 121 1-14. (https:// doi.org/10.1002/aja.1001210102)

el-Sayed MG, el-Sayed MT, Elazab Abd el S, Hafeiz MH, el-Komy AA \& Hassan E 1998 Effects of some beta-adrenergic blockers on male fertility parameters in rats. Deutsche Tierärztliche Wochenschrift 105 10-12.

Fibbi B, Filippi S, Morelli A, Vignozzi L, Silvestrini E, Chavalmane A, de Vita G, Marini M, Gacci M \& Manieri C et al. 2009 Estrogens regulate humans and rabbit epididymal contractility through the RhoA/Rhokinase pathway. Journal of Sexual Medicine 6 2173-2186.

Filippi S, Morelli A, Vignozzi L, Vannelli GB, Marini M, Ferruzzi P, Mancina R, Crescioli C, Mondaini N \& Forti G et al. 2005 Oxytocin mediates the estrogen-dependent contractile activity of endothelin-1 in human and rabbit epididymis. Endocrinology 146 3506-3517. (https:// doi.org/10.1210/en.2004-1628)

Gacci M, Andersson K-E, Chapple C, Maggi M, Mirone V, Oelke M, Porst H, Roehrborn C, Stief C \& Giuliano F 2016 Latest evidence on the use of phosphodiesterase type 5 inhibitors for the treatment of lower urinary tract symptoms secondary to benign prostatic hyperplasia. European Urology 70 124-133. (https://doi.org/10.1016/j.eururo.2015.12.048)

Gao DY, Zhang BL, Leung MCT, Au SCL, Wong PYD \& Shum WWC 2016 Coupling of TRPV6 and TMEM16A in epithelial principal cells of the rat epididymis. Journal of General Physiology 148 161-182. (https://doi. org/10.1085/jgp.201611626)

Ghofrani HA, Osterloh IH \& Grimminger F 2006 Sildenafil: from angina to erectile dysfunction to pulmonary hypertension and beyond. Nature Reviews: Drug Discovery 5 689-702. (https://doi.org/10.1038/nrd2030)

Graham RM, Perez DM, Hwa J \& Piascik MT 1996 alpha 1-Adrenergic receptor subtypes. Molecular structure, function, and signaling. Circulation Research $\mathbf{7 8} 737-749 . \quad$ (https://doi.org/10.1161/01. RES.78.5.737)

Greenberg J, Schubert W, Metz J, Yanaihara N \& Forssmann WG 1985 Studies of the guinea-pig epididymis. III. Innervation of epididymal segments. Cell and Tissue Research 239 395-404.

Grove KL \& Speth RC 1989 Rat epididymis contains functional angiotensin II receptors. Endocrinology 125 223-230. (https://doi.org/10.1210/endo125-1-223)

Hagaman JR, Moyer JS, Bachman ES, Sibony M, Magyar PL, Welch JE, Smithies O, Krege JH \& O'Brien DA 1998 Angiotensin-converting enzyme and male fertility. PNAS 95 2552-2557. (https://doi.org/10.1073/ pnas.95.5.2552)

Hay DW \& Wadsworth RM 1982 The contractile effects of 5-hydroxytryptamine on the rat isolated vas deferens. British Journal of Pharmacology 77 605-613. (https://doi.org/10.1111/j.1476-5381.1982. tb09338.x)

Haynes JM, Hill SJ \& Selbie LA 1997 Neuropeptide Y (NPY) and peptide YY (PYY) effects in the epididymis of the guinea-pig: evidence of a prejunctional PYY-selective receptor. British Journal of Pharmacology 122 1530-1536. (https://doi.org/10.1038/sj.bjp.0701544)

Hess RA, Gist DH, Bunick D, Lubahn DB, Farrell A, Bahr J, Cooke PS \& Greene GL 1997 Estrogen receptor (alpha and beta) expression in the excurrent ducts of the adult male rat reproductive tract. Journal of Andrology 18 602-611.

Hess RA, Fernandes SAF, Gomes GRO, Oliveira CA, Lazari MFM \& Porto CS 2011 Estrogen and its receptors in efferent ductules and epididymis. Journal of Andrology 32 600-613. (https://doi.org/10.2164/ jandrol.110.012872)

Heuser A, Mecklenburg L, Ockert D, Kohler M \& Kemkowski J 2013 Selective inhibition of PDE4 in Wistar rats can lead to dilatation in testis, efferent ducts, and epididymis and subsequent formation of sperm granulomas. Toxicologic Pathology 41 615-627. (https://doi. org/10.1177/0192623312463783)

Hib J 1974 The in vitro effects of oxytocin and vasopressin on spontaneous contractility of the mouse cauda epididymidis. Biology of Reproduction 11 436-439. (https://doi.org/10.1095/biolreprod11.4.436)

Hib J 1976 Effects of autonomic drugs on epididymal contractions. Fertility and Sterility 27 951-956. (https://doi.org/10.1016/S00150282(16)42024-8)

Hib J 1988 Changes in the contractile activity of the male genital tract as a consequence of vasectomy. Acta Physiologica et Pharmacologica Latinoamericana 38 159-165.

Hib J \& Caldeyro-Barcia R 1974 Neurohormonal control of epididymal contractions. Basic Life Sciences 4 (PT. B) 111-126.

Hib J \& Oscar P 1978 Effects of prostaglandins and indomethacin on rat epididymal responses to norepinephrine and acetylcholine. Archives of Andrology 1 43-47. (https://doi.org/10.3109/01485017808988316)

Hib J \& Ponzio RO 1977 Effects of cyproterone acetate on spontaneous contractility of the rat epididymis. Andrologia 9 329-331. (https://doi. org/10.1111/j.1439-0272.1977.tb01682.x)

Hinton BT, Lan ZJ, Lye RJ \& Labus JC 2000 Regulation of epididymal function by testicular factors: the lumicrine hypothesis. In The Testis: From Stem Cell to Sperm Function, pp 163-173. Ed E Goldberg. New York: Springer.

Hinton BT, Galdamez MM, Sutherland A, Bomgardner D, Xu B, AbdelFattah R \& Yang L 2011 How do you get six meters of epididymis inside a human scrotum? Journal of Andrology 32 558-564. (https://doi. org/10.2164/jandrol.111.013029)

Hofmann F \& Wegener JW 2013 cGMP-dependent protein kinases (cGK). In Guanylate Cyclase and Cyclic GMP, pp 17-50. Eds T Krieg \& R Lukowski. Totowa, NJ: Humana Press. 
Holstein AF 1969 Morphologische studien am nebenhoden des menschen. Zwanglose Abhandlungen aus dem Gebiet der Normalen und Pathologischen Anatomie 20 1-91.

Holstein AF 2008 Männliche geschlechtsorgane. In Benninghoff, Anatomie. Makroskopische Anatomie, Embryologie und Histologie des Menschen, 15th ed, pp 67-114. München: Urban \& Schwarzenberg.

Hosang K \& Scheit KH 1994 cDNA cloning identified a calmodulinbinding protein in bovine seminal plasma as bovine C-type natriuretic peptide. DNA and Cell Biology 13 409-417. (https://doi.org/10.1089/ dna.1994.13.409)

Huang F, Rock JR, Harfe BD, Cheng T, Huang X, Jan YN \& Jan LY 2009 Studies on expression and function of the TMEM16A calcium-activated chloride channel. PNAS 106 21413-21418. (https://doi.org/10.1073/ pnas.0911935106)

Ibrahim E, Lynne CM \& Brackett NL 2016 Male fertility following spinal cord injury: an update. Andrology 4 13-26. (https://doi.org/10.1111/ andr.12119)

Jaakkola UM \& Talo A 1981 Effects of oxytocin and vasopressin on electrical and mechanical activity of the rat epididymis in vitro. Journal of Reproduction and Fertility 63 47-51. (https://doi.org/10.1530/ jrf.0.0630047)

Jaakkola UM \& Talo A 1982 Relation of electrical activity to luminal transport in the cauda epididymidis of the rat in vitro. Journal of Reproduction and Fertility 64 121-126. (https://doi.org/10.1530/jrf.0.0640121)

Jaakkola UM \& Talo A 1983 Movements of the luminal contents in two different regions of the caput epididymidis of the rat in vitro. Journal of Physiology 336 453-463. (https://doi.org/10.1113/jphysiol.1983. sp014590)

Jaleel M, London RM, Eber SL, Forte LR \& Visweswariah SS 2002 Expression of the receptor guanylyl cyclase $\mathrm{C}$ and its ligands in reproductive tissues of the rat: a potential role for a novel signaling pathway in the epididymis. Biology of Reproduction 67 1975-1980. (https://doi.org/10.1095/ biolreprod.102.006445)

Jen PY, Dixon JS \& Gosling JA 1997 Co-localization of nitric oxide synthase, neuropeptides and tyrosine hydroxylase in nerves supplying the human post-natal vas deferens and seminal vesicle. British Journal of Urology $\mathbf{8 0}$ 291-299. (https://doi.org/10.1046/j.1464-410X.1997.00219.x)

Jimenez-Trejo F, Tapia-Rodriguez M, Queiroz DBC, Padilla P, Avellar MCW, Manzano PR, Manjarrez-Gutierrez G \& Gutierrez-Ospina G 2007 Serotonin concentration, synthesis, cell origin, and targets in the rat caput epididymis during sexual maturation and variations associated with adult mating status: morphological and biochemical studies. Journal of Andrology 28 136-149. (https://doi.org/10.2164/jandrol.106.000653)

Johns A, Steger RW \& Bartke A 1983 The effects of photoperiod on the responses of the hamster vas deferens to nerve stimulation. Journal of Pharmacology and Experimental Therapeutics 224 155-160.

Johnson AL \& Howards SS 1976 Intratubular hydrostatic pressure in testis and epididymis before and after long-term vasectomy in the guinea pig. Biology of Reproduction 14 371-376. (https://doi.org/10.1095/ biolreprod14.4.371)

Jones RC \& Clulow J 1987 Regulation of the elemental composition of the epididymal fluids in the tammar, Macropus eugenii. Journal of Reproduction and Fertility 81 583-590. (https://doi.org/10.1530/ jrf.0.0810583)

Kaleczyc J, Majewski M, Calka J \& Lakomy M 1993 Adrenergic innervation of the epididymis, vas deferens, accessory genital glands and urethra in the boar. Folia Histochemica et Cytobiologica 31 117-123.

Kaplan SA 2009 Side effects of alpha-blocker use: retrograde ejaculation. Reviews in Urology 11 (Supplement 1) S14-S18.

Kastin AJ, Coy DH, Schally AV \& Meyers CA 1978 Activity of VIP, somatostatin and other peptides in the mouse vas deferens assay. Pharmacology, Biochemistry, and Behavior 9 673-676. (https://doi. org/10.1016/0091-3057(78)90220-4)

Kauffenstein G, Pelletier J, Lavoie EG, Kukulski F, Martin-Satue M, Dufresne SS, Frenette J, Ribas Furstenau C, Sereda MJ \& Toutain B et al. 2014 Nucleoside triphosphate diphosphohydrolase-1 ectonucleotidase is required for normal vas deferens contraction and male fertility through maintaining P2X1 receptor function. Journal of Biological Chemistry 289 28629-28639. (https://doi.org/10.1074/jbc.M114.604082)

Kempinas WD, Suarez JD, Roberts NL, Strader LF, Ferrell J, Goldman JM, Narotsky MG, Perreault SD, Evenson DP \& Ricker DD et al. 1998 Fertility of rat epididymal sperm after chemically and surgically induced sympathectomy. Biology of Reproduction 59 897-904. (https://doi. org/10.1095/biolreprod59.4.897)

Kierszenbaum AL \& Tres LL 2016 Histology and Cell Biology: An Introduction to Pathology. Philadelphia, PA: Elsevier.

Killam AL, Watts SW \& Cohen ML 1995 Role of alpha 1-adrenoceptors and 5-HT2 receptors in serotonin-induced contraction of rat prostate: autoradiographical and functional studies. European Journal of Pharmacology 273 7-14. (https://doi.org/10.1016/00142999(94)00613-C)

Kim SZ, Kang SY, Lee SJ \& Cho KW 2000 Localization of receptors for natriuretic peptide and endothelin in the duct of the epididymis of the freshwater turtle. General and Comparative Endocrinology 118 26-38. (https://doi.org/10.1006/gcen.1999.7445)

Klein MK, Haberberger RV, Hartmann P, Faulhammer P, Lips KS, Krain B, Wess J, Kummer W \& Konig P 2009 Muscarinic receptor subtypes in ciliadriven transport and airway epithelial development. European Respiratory Journal 33 1113-1121. (https://doi.org/10.1183/09031936.00015108)

Knight TW 1974 A qualitative study of factors affecting the contractions of the epididymis and ductus deferens of the ram. Journal of Reproduction and Fertility 40 19-29. (https://doi.org/10.1530/jrf.0.0400019)

Knowles RG \& Moncada S 1994 Nitric oxide synthases in mammals. Biochemical Journal 298 249-258. (https://doi.org/10.1042/ bj2980249)

Kobayashi K, Masumori N, Hisasue S-i, Kato R, Hashimoto K, Itoh N \& Tsukamoto T 2008 Inhibition of seminal emission is the main cause of anejaculation induced by a new highly selective alpha1A-blocker in normal volunteers. Journal of Sexual Medicine 5 2185-2190. (https:// doi.org/10.1111/j.1743-6109.2008.00779.x)

Koslov DS \& Andersson K-E 2013 Physiological and pharmacological aspects of the vas deferens-an update. Frontiers in Pharmacology 4101.

Krutskikh A, de Gendt K, Sharp V, Verhoeven G, Poutanen M \& Huhtaniemi I 2011 Targeted inactivation of the androgen receptor gene in murine proximal epididymis causes epithelial hypotrophy and obstructive azoospermia. Endocrinology 152 689-696. (https://doi. org/10.1210/en.2010-0768)

Kryukova OV, Tikhomirova VE, Golukhova EZ, Evdokimov VV, Kalantarov GF, Trakht IN, Schwartz DE, Dull RO, Gusakov AV \& Uporov IV et al. 2015 Tissue specificity of human angiotensin I-converting enzyme. PLoS ONE 10 e0143455. (https://doi.org/10.1371/ journal.pone.0143455)

Kuhn M 2016 Molecular physiology of membrane guanylyl cyclase receptors. Physiological Reviews 96 751-804. (https://doi.org/10.1152/ physrev.00022.2015)

Kunts A \& Morris RE Jr1946 Components and distribution of the spermatic nerves and the nerves of the vas deferens. Journal of Comparative Neurology 85 33-44. (https://doi.org/10.1002/cne.900850104)

Laitinen L \& Talo A 1981 Effects of adrenergic and cholinergic drugs on electrical and mechanical activities of the rat cauda epididymidis in vitro. Journal of Reproduction and Fertility 63 205-209. (https://doi. org/10.1530/jrf.0.0630205)

Lang RJ, Exintaris B, Teele ME, Harvey J \& Klemm MF 1998 Electrical basis of peristalsis in the mammalian upper urinary tract. Clinical and Experimental Pharmacology and Physiology 25 310-321. (https://doi. org/10.1111/j.1440-1681.1998.tb02357.x)

Lazarus M, Munday CJ, Eguchi N, Matsumoto S, Killian GJ, Kubata BK \& Urade Y 2002 Immunohistochemical localization of microsomal PGE synthase-1 and cyclooxygenases in male mouse reproductive organs. Endocrinology $143 \quad$ 2410-2419. (https://doi.org/10.1210/ endo.143.6.8872)

Lee HY, Bardini M \& Burnstock G 2000 P2X receptor immunoreactivity in the male genital organs of the rat. Cell and Tissue Research 300 321-330. (https://doi.org/10.1007/s004410000207)

Leng G \& Sabatier N 2017 Oxytocin - the sweet hormone? Trends in Endocrinology and Metabolism 28 365-376. (https://doi.org/10.1016/j. tem.2017.02.007)

Leung GP, Dun SL, Dun NJ \& Wong PY 1999 Serotonin via 5-HT1B and 5 - $\mathrm{HT} 2 \mathrm{~B}$ receptors stimulates anion secretion in the rat epididymal epithelium. Journal of Physiology 519 Pt 3 657-667. (https://doi. org/10.1111/j.1469-7793.1999.0657n.x)

Lishko PV, Botchkina IL \& Kirichok Y 2011 Progesterone activates the principal Ca2+ channel of human sperm. Nature 471 387-391. (https:// doi.org/10.1038/nature09767) 
Lugnier C 2006 Cyclic nucleotide phosphodiesterase (PDE) superfamily: a new target for the development of specific therapeutic agents. Pharmacology and Therapeutics 109 366-398.

Lundberg JM, Terenius L, Hokfelt T \& Goldstein M 1983 High levels of neuropeptide $\mathrm{Y}$ in peripheral noradrenergic neurons in various mammals including man. Neuroscience Letters 42 167-172. (https://doi. org/10.1016/0304-3940(83)90401-9)

MacDonald A \& McGrath JC 1980 The effects of castration on neurotransmission in the rat vas deferens. British Journal of Pharmacology 69 49-58. (https://doi.org/10.1111/j.1476-5381.1980.tb10882.x)

Markkula-Viitanen M, Nikkanen V \& Talo A 1979 Electrical activity and intraluminal pressure of the cauda epididymidis of the rat. Journal of Reproduction and Fertility $\mathbf{5 7}$ 431-435. (https://doi.org/10.1530/ jrf.0.0570431)

Martinez-Traverso GB \& Pearl CA 2015 Immunolocalization of G protein-coupled estrogen receptor in the rat epididymis. Reproductive Biology and Endocrinology 13 48. (https://doi.org/10.1186/s12958015-0042-z)

Martín-Satué M, Lavoie EG, Pelletier J, Fausther M, Csizmadia E, Guckelberger O, Robson SC \& Sévigny J 2009 Localization of plasma membrane bound NTPDases in the murine reproductive tract. Histochemistry and Cell Biology 131 615-628.

Melin P 1970 In vivo recording of contractile activity of male accessory genital organs in rabbits. Acta Physiologica Scandinavica 79 109-113. (https://doi.org/10.1111/j.1748-1716.1970.tb04706.x)

Mewe M, Bauer CK, Müller D \& Middendorff R 2006a Regulation of spontaneous contractile activity in the bovine epididymal duct by cyclic guanosine 5'-monophosphate-dependent pathways. Endocrinology 147 2051-2062. (https://doi.org/10.1210/en.2005-1324)

Mewe M, Bauer CK, Schwarz JR \& Middendorff R 2006b Mechanisms regulating spontaneous contractions in the bovine epididymal duct. Biology of Reproduction 75 651-659. (https://doi.org/10.1095/ biolreprod.106.054577)

Mewe M, Wulfsen I, Middendorff R \& Bauer CK 2007 Differential modulation of bovine epididymal activity by oxytocin and noradrenaline. Reproduction 134 493-501. (https://doi.org/10.1530/REP-07-0220)

Michel V, Duan Y, Stoschek E, Bhushan S, Middendorff R, Young JM, Loveland KL, Kretser DMD, Hedger MP \& Meinhardt A 2016 Uropathogenic Escherichia coli causes fibrotic remodelling of the epididymis. Journal of Pathology 240 15-24. (https://doi.org/10.1002/ path.4748)

Michel V, Pilatz A, Hedger MP \& Meinhardt A 2015 Epididymitis: revelations at the convergence of clinical and basic sciences. Asian Journal of Andrology 17 756-763.

Mietens A, Tasch S, Feuerstacke C, Eichner G, Volkmann J, Schermuly RT, Grimminger F, Müller D \& Middendorff R 2012 Phosphodiesterase 5 (PDE5) inhibition, ANP and NO rapidly reduce epididymal duct contractions, but long-term PDE5 inhibition in vivo does not. Molecular and Cellular Endocrinology 349 145-153. (https://doi.org/10.1016/j. mce.2011.09.039)

Mietens A, Tasch S, Stammler A, Konrad L, Feuerstacke C \& Middendorff R 2014 Time-lapse imaging as a tool to investigate contractility of the epididymal duct-effects of cGMP signaling. PLOS ONE 9 e92603. (https://doi.org/10.1371/journal.pone.0092603)

Mitchell GA 1935 The innervation of the kidney, ureter, testicle and epididymis. Journal of Anatomy 70 10.15-32.15.

Movsesian M 2016 Novel approaches to targeting PDE3 in cardiovascular disease. Pharmacology and Therapeutics 163 74-81.

Müller D, Cortes-Dericks L, Budnik LT, Brunswig-Spickenheier B, Pancratius M, Speth RC, Mukhopadhyay AK \& Middendorff R 2006 Homologous and lysophosphatidic acid-induced desensitization of the atrial natriuretic peptide receptor, guanylyl cyclase-A, in MA-10 Leydig cells. Endocrinology 147 2974-2985.

Müller D, Mukhopadhyay AK, Davidoff MS \& Middendorff R 2011 Cyclic GMP signaling in rat urinary bladder, prostate, and epididymis: tissuespecific changes with aging and in response to Leydig cell depletion. Reproduction 142 333-343.

Mulryan K, Gitterman DP, Lewis CJ, Vial C, Leckie BJ, Cobb AL, Brown JE, Conley EC, Buell G \& Pritchard CA et al. 2000 Reduced vas deferens contraction and male infertility in mice lacking $\mathrm{P} 2 \mathrm{X} 1$ receptors. Nature 403 86-89. (https://doi.org/10.1038/47495)
Muratori G \& Contro S 1951 Osservazioni sui movimenti del canale dell'epididimo. Bollettino Della Societa Italiana di Biologia Sperimentale 27 538-539.

Nielsen SJ, Gotze JP, Jensen HL \& Rehfeld JF 2008 ProCNP and CNP are expressed primarily in male genital organs. Regulatory Peptides $\mathbf{1 4 6}$ 204-212. (https://doi.org/10.1016/j.regpep.2007.09.022)

Noreikat K, Wolff M, Kummer W \& Kolle S 2012 Ciliary activity in the oviduct of cycling, pregnant, and muscarinic receptor knockout mice. Biology of Reproduction 86120.

Nouhouayi Y \& Negulesco I 1985 Innervation adrenergique des cellules musculaires lisses de la queue de l'epididyme chez la souris. Acta Anatomica 121 59-62. (https://doi.org/10.1159/000145943)

Oliveira RL, Nogueira JC, Mahecha GAB \& Oliveira CA 2012 Seasonal variation in estrogen receptor $\mathrm{ER} \alpha$, but not $\mathrm{ER} \beta$, androgen receptor and aromatase, in the efferent ductules and epididymis of the big fruit-eating bat Artibeus lituratus. General and Comparative Endocrinology $\mathbf{1 7 9}$ 1-13. (https://doi.org/10.1016/j.ygcen.2012.06.028)

Pagès L, Gavaldà A \& Lehner MD 2009 PDE4 inhibitors: a review of current developments (2005-2009). Expert Opinion on Therapeutic Patents 19 1501-1519.

Pankow K, Schwiebs A, Becker M, Siems W-E, Krause G \& Walther T 2009 Structural substrate conditions required for neutral endopeptidasemediated natriuretic peptide degradation. Journal of Molecular Biology 393 496-503. (https://doi.org/10.1016/j.jmb.2009.08.025)

Peri A, Fantoni G, Granchi S, Vannelli GB, Barni T, Amerini S, Pupilli C, Barbagli G, Forti G \& Serio M et al. 1997 Gene expression of endothelin-1, endothelin-converting enzyme-1, and endothelin receptors in human epididymis. Journal of Clinical Endocrinology and Metabolism 82 3797-3806.

Pholpramool C \& Triphrom N 1984 Effects of cholinergic and adrenergic drugs on intraluminal pressures and contractility of the rat testis and epididymis in vivo. Journal of Reproduction and Fertility 71 181-188. (https://doi.org/10.1530/jrf.0.0710181)

Potter LR 2011 Natriuretic peptide metabolism, clearance and degradation. FEBS Journal 278 1808-1817. (https://doi.org/10.1111/j.17424658.2011.08082.x)

Potter LR \& Garbers DL 1992 Dephosphorylation of the guanylyl cyclase-A receptor causes desensitization. Journal of Biological Chemistry 267 14531-14534.

Queiroz DBC, Mendes FR, Porto CS \& Avellar MCW 2002 Alpha1adrenoceptor subtypes in rat epididymis and the effects of sexual maturation. Biology of Reproduction 66 508-515. (https://doi. org/10.1095/biolreprod66.2.508)

Queiroz DBC, Porto CS, Grossman G, Petrusz P \& Avellar MCW 2008 Immunolocalization of alpha(1A)-adrenoceptors in rat and human epididymis. Cell and Tissue Research 332 509-522. (https://doi. org/10.1007/s00441-008-0576-x)

Rabe KF 2011 Update on roflumilast, a phosphodiesterase 4 inhibitor for the treatment of chronic obstructive pulmonary disease. British Journal of Pharmacology 163 53-67. (https://doi.org/10.1111/j.14765381.2011.01218.x)

Rago V, Romeo F, Giordano F, Malivindi R, Pezzi V, Casaburi I \& Carpino A 2018 Expression of oestrogen receptors (GPER, ESR1, ESR2) in human ductuli efferentes and proximal epididymis. Andrology 6 192-198. (https://doi.org/10.1111/andr.12443)

Reckmann AN, Tomczyk CUM, Davidoff MS, Michurina TV, Arnhold S, Müller D, Mietens A \& Middendorff R 2018 Nestin in the epididymis is expressed in vascular wall cells and is regulated during postnatal development and in case of testosterone deficiency. PLOS ONE 13 e0194585. (https://doi.org/10.1371/journal.pone.0194585)

Risley PL \& Skrepetos CN 1964 Histochemical distribution of cholinesterases in the testis, epididymis and vas deferens of the rat. Anatomical Record 148 231-249. (https://doi.org/10.1002/ar.1091480213)

Robaire B \& Hamzeh M 2011 Androgen action in the epididymis. Journal of Andrology 32 592-599. (https://doi.org/10.2164/jandrol.111.014266)

Robaire B \& Henderson NA 2006 Actions of 5alpha-reductase inhibitors on the epididymis. Molecular and Cellular Endocrinology 250 190-195. (https://doi.org/10.1016/j.mce.2005.12.044)

Robaire B \& Hinton BT 2015 The epididymis. In Knobil and Neill's Physiology of Reproduction: Two-Volume Set, 4th ed, pp 691-771. Eds TM Plant \& AJ Zeleznik. Burlington: Elsevier Science. 
Saboor F, Reckmann AN, Tomczyk CUM, Peters DM, Weissmann N, Kaschtanow A, Schermuly RT, Michurina TV, Enikolopov G \& Müller D et al. 2016 Nestin-expressing vascular wall cells drive development of pulmonary hypertension. European Respiratory Journal 47 876-888. (https://doi.org/10.1183/13993003.00574-2015)

Sakkas LI, Mavropoulos A \& Bogdanos DP 2017 Phosphodiesterase 4 inhibitors in immune-mediated diseases: mode of action, clinical applications, current and future perspectives. Current Medicinal Chemistry 24 3054-3067. (https://doi.org/10.2174/092986732466617 0530093902)

Sanbe A, Tanaka Y, Fujiwara Y, Tsumura H, Yamauchi J, Cotecchia S, Koike K, Tsujimoto G \& Tanoue A 2007 Alpha1-adrenoceptors are required for normal male sexual function. British Journal of Pharmacology 152 332-340. (https://doi.org/10.1038/sj.bjp.0707366)

Semet M, Paci M, Saïas-Magnan J, Metzler-Guillemain C, Boissier R, Lejeune H \& Perrin J 2017 The impact of drugs on male fertility: a review. Andrology 5 640-663. (https://doi.org/10.1111/andr.12366)

Shum WWC, Da Silva N, McKee M, Smith PJS, Brown D \& Breton S 2008 Transepithelial projections from basal cells are luminal sensors in pseudostratified epithelia. Cell 135 1108-1117. (https://doi. org/10.1016/j.cell.2008.10.020)

Simon P, Feuerstacke C, Kaese M, Saboor F, Middendorff R \& Galuska SP 2015 Polysialylation of NCAM characterizes the proliferation period of contractile elements during postnatal development of the epididymis. PLOS ONE 10 e0123960. (https://doi.org/10.1371/journal. pone.0123960)

Siu ER, Yasuhara F, Marostica E, Avellar MCW \& Porto CS 2006 Expression and localization of muscarinic acetylcholine receptor subtypes in rat efferent ductules and epididymis. Cell and Tissue Research 323 157-166. (https://doi.org/10.1007/s00441-005-0054-7)

Smith-Harrison LI, Patel A \& Smith RP 2016 The devil is in the details: an analysis of the subtleties between phosphodiesterase inhibitors for erectile dysfunction. Translational Andrology and Urology 5 181-186. (https://doi.org/10.21037/tau.2016.03.01)

Song Z \& Albers HE 2017 Cross-talk among oxytocin and argininevasopressin receptors: relevance for basic and clinical studies of the brain and periphery. Frontiers in Neuroendocrinology Epub. (https://doi. org/10.1016/j.yfrne.2017.10.004)

Sorrentino C, Silvestrini B, Braghiroli L, Chung SS, Giacomelli S, Leone MG, Xie Y, Sui Y, Mo M \& Cheng CY 1998 Rat prostaglandin D2 synthetase: its tissue distribution, changes during maturation, and regulation in the testis and epididymis. Biology of Reproduction 59 843-853. (https://doi.org/10.1095/biolreprod59.4.843)

Stammler A, Hau T, Bhushan S, Meinhardt A, Jonigk D, Lippmann T, Pilatz A, Schneider-Hüther I \& Middendorff R 2015 Epididymitis: ascending infection restricted by segmental boundaries. Human Reproduction 30 1557-1565. (https://doi.org/10.1093/humrep/dev112)

Stanfield KM \& Khan KNM 2003 Localization of COX-2 in the male reproductive tract during sexual maturation. Inflammopharmacology $\mathbf{1 1}$ 259-266. (https://doi.org/10.1163/156856003322315604)

Strünker T, Goodwin N, Brenker C, Kashikar ND, Weyand I, Seifert R \& Kaupp UB 2011 The CatSper channel mediates progesterone-induced $\mathrm{Ca} 2+$ influx in human sperm. Nature 471 382-386.

Studdard PW, Stein JL \& Cosentino MJ 2002 The effects of oxytocin and arginine vasopressin in vitro on epididymal contractility in the rat. International Journal of Andrology 25 65-71. (https://doi.org/10.1046/ j.1365-2605.2002.00323.x)

Sum CS \& Cheung WT 1995 Characterization of contractile response to angiotensin in epididymal rat vas deferens. Pharmacology 51 105-111. (https://doi.org/10.1159/000139322)

Talo A, Jaakkola UM \& Markkula-Viitanen M 1979 Spontaneous electrical activity of the rat epididymis in vitro. Journal of Reproduction and Fertility 57 423-429. (https://doi.org/10.1530/jrf.0.0570423)

Taylor SN 2015 Epididymitis. Clinical Infectious Diseases 61 (Supplement 8) S770-S773. (https://doi.org/10.1093/cid/civ812)

Terawaki S-i, Kitano K \& Hakoshima T 2007 Structural basis for type II membrane protein binding by ERM proteins revealed by the radixin-neutral endopeptidase 24.11 (NEP) complex. Journal of Biological Chemistry 282 19854-19862. (https://doi.org/10.1074/jbc. M609232200)

Thong A, Müller D, Feuerstacke C, Mietens A, Stammler A \& Middendorff R 2014 Neutral endopeptidase (CD10) is abundantly expressed in the epididymis and localized to a distinct population of epithelial cells - its relevance for CNP degradation. Molecular and Cellular Endocrinology 382 234-243. (https://doi.org/10.1016/j.mce.2013.09.027)

Toda K, Okada T, Hayashi Y \& Saibara T 2008 Preserved tissue structure of efferent ductules in aromatase-deficient mice. Journal of Endocrinology 199 137-146. (https://doi.org/10.1677/JOE-08-0257)

Torres T \& Puig L 2017 Apremilast: a novel oral treatment for psoriasis and psoriatic arthritis. American Journal of Clinical Dermatology 19 23-32. (https://doi.org/10.1007/s40257-017-0302-0)

Trybek G, Kolasa A, Marchlewicz M, Wenda-Rózewicka L \& Wiszniewska B 2005 Immunolocalization of androgen receptor in the epididymis of rats with dihydrotestosterone deficiency. Reproductive Biology 5 291-301.

Turner TT 1984 Resorption versus secretion in the rat epididymis. Journal of Reproduction and Fertility 72 509-514. (https://doi.org/10.1530/ jrf.0.0720509)

Turner TT, Bomgardner D, Jacobs JP \& Nguyen QAT 2003 Association of segmentation of the epididymal interstitium with segmented tubule function in rats and mice. Reproduction 125 871-878. (https://doi. org/10.1530/rep.0.1250871)

Turner TT, Johnston DS, Jelinsky SA, Tomsig JL \& Finger JN 2007 Segment boundaries of the adult rat epididymis limit interstitial signaling by potential paracrine factors and segments lose differential gene expression after efferent duct ligation. Asian Journal of Andrology 9 565-573. (https://doi.org/10.1111/j.1745-7262.2007.00302.x)

van de Velde RL \& Risley PL 1963 The origin and development of smooth muscle and contractility in the ductus epididymidis of the rat. Journal of Embryology and Experimental Morphology 11 369-382.

Ventura S \& Pennefather JN 1991 Sympathetic co-transmission to the cauda epididymis of the rat: characterization of postjunctional adrenoceptors and purinoceptors. British Journal of Pharmacology 102 540-544. (https://doi.org/10.1111/j.1476-5381.1991.tb12207.x)

Weissgerber P, Kriebs U, Tsvilovskyy V, Olausson J, Kretz O, Stoerger C, Vennekens R, Wissenbach U, Middendorff R \& Flockerzi V et al. 2011 Male fertility depends on $\mathrm{Ca}(2)+$ absorption by TRPV 6 in epididymal epithelia. Science Signaling 4 ra27.

Weissgerber P, Kriebs U, Tsvilovskyy V, Olausson J, Kretz O, Stoerger C, Mannebach S, Wissenbach U, Vennekens R \& Middendorff $R$ et al. 2012 Excision of Trpv 6 gene leads to severe defects in epididymal Ca2+ absorption and male fertility much like single D541A pore mutation. Journal of Biological Chemistry 287 17930-17941. (https://doi. org/10.1074/jbc.M111.328286)

Welsh M, Moffat L, McNeilly A, Brownstein D, Saunders PTK, Sharpe RM \& Smith LB 2011 Smooth muscle cell-specific knockout of androgen receptor: a new model for prostatic disease. Endocrinology 152 3541-3551. (https://doi.org/10.1210/en.2011-0282)

Welsh M, Saunders PTK, Atanassova N, Sharpe RM \& Smith LB 2009 Androgen action via testicular peritubular myoid cells is essential for male fertility. FASEB Journal 23 4218-4230. (https://doi.org/10.1096/ fj.09-138347)

White CW, Choong Y-T, Short JL, Exintaris B, Malone DT, Allen AM, Evans RJ \& Ventura S 2013 Male contraception via simultaneous knockout of $\alpha 1 \mathrm{~A}$-adrenoceptors and P2X1-purinoceptors in mice. PNAS 110 20825-20830. (https://doi.org/10.1073/pnas.1318624110)

Whittington K, Assinder S, Parkinson T, Lapwood K \& Nicholson H 2001 Function and localization of oxytocin receptors in the reproductive tissue of rams. Reproduction 122 317-325. (https://doi.org/10.1530/ rep.0.1220317)

Wiszniewska B, Kurzawa R, Ciechanowicz A \& Machaliński B 1997 Inducible nitric oxide synthase in the epithelial epididymal cells of the rat. Reproduction, Fertility and Development 9 789-794. (https://doi. org/10.1071/R97063)

Wong PYD \& Uchendu CN 1990 The role of angiotensin-converting enzyme in the rat epididymis. Journal of Endocrinology 125 457-465. (https://doi.org/10.1677/joe.0.1250457)

Wong PY, Chan HC, Leung PS, Chung YW, Wong YL, Lee WM, Ng V \& Dun NJ 1999 Regulation of anion secretion by cyclo-oxygenase and prostanoids in cultured epididymal epithelia from the rat. Journal of Physiology 514 809-820. (https://doi.org/10.1111/j.14697793.1999.809ad.x)

Yang Z-W, Kong L-S, Guo Y, Yin J-Q \& Mills N 2006 Histological changes of the testis and epididymis in adult rats as a result of Leydig cell destruction after ethane dimethane sulfonate treatment: a morphometric 
study. Asian Journal of Andrology 8 289-299. (https://doi.org/10.1111/ j.1745-7262.2006.00140.x)

Zhang C, Lueptow LM, Zhang H-T, O'Donnell JM \& Xu Y 2017 The role of phosphodiesterase-2 in psychiatric and neurodegenerative disorders. Advances in Neurobiology 17 307-347.

Zhou Q, Nie R, Prins GS, Saunders PTK, Katzenellenbogen BS \& Hess RA 2002 Localization of androgen and estrogen receptors in adult male mouse reproductive tract. Journal of Andrology 23 870-881.

Zini A, O'Bryan MK, Magid MS \& Schlegel PN 1996 Immunohistochemical localization of endothelial nitric oxide synthase in human testis, epididymis, and vas deferens suggests a possible role for nitric oxide in spermatogenesis, sperm maturation, and programmed cell death.
Biology of Reproduction 55 935-941. (https://doi.org/10.1095/ biolreprod55.5.935)

Received 13 December 2017

First decision 11 June 2018

Revised manuscript received 17 May 2018

Accepted 11 June 2018 